Journal of Zhejiang University-SCIENCE A (Applied Physics \& Engineering)

ISSN 1673-565X (Print); ISSN 1862-1775 (Online)

www.zju.edu.cn/jzus; www.springerlink.com

E-mail: jzus@zju.edu.cn

\title{
Review:
}

\section{Interactions between engineered nanomaterials and agricultural crops: implications for food safety"}

\author{
Ying-qing DENG ${ }^{1}$, Jason C. WHITE ${ }^{2}$, Bao-shan $\mathrm{XING}^{\dagger 11}$ \\ ('Stockbridge School of Agriculture, University of Massachusetts, Amherst, MA 01003, USA) \\ ( ${ }^{2}$ Department of Analytical Chemistry, The Connecticut Agricultural Experiment Station, New Haven, CT 06504, USA) \\ †E-mail: bx@umass.edu \\ Received June 8, 2014; Revision accepted June 24, 2014; Crosschecked July 18, 2014
}

\begin{abstract}
Engineered nanomaterials (ENMs) are being discharged into the environment and to agricultural fields, with unknown impacts on crop species. In this paper, we review the literature on ENMs uptake, translocation/distribution, and generational transmission in various crop species, as well as potential material trophic transfer. Previous studies reveal that ENM-exposed crops exhibit adaptive processes in response to stress, including endocytosis/endosome activities, production of antioxidant enzymes, regulation of genes related to cell division/extension and membrane transport. Some agronomic traits of crops are compromised during the adaption response, including photosynthesis, fruit yields, nutritional quality and nitrogen fixation. Cultivation of crops in ENMs-contaminated environments has unknown implications for food safety and quality. Notably, mechanisms underlying ENMs phytotoxicity and bioavailability are unclear. Additional investigations focused on developing novel techniques for in vivo identification/characterization of ENMs are critically needed. Given the abundance of uncertainty in the literature, it is clear that more research is urgently needed in the area of ENMs-crop interactions; only then can one accurately assess exposure, risk, and overall implications for food safety and also enable guidance development for the sustainable implementation of nanotechnology in agriculture and food production/manufacturing.
\end{abstract}

Key words: Engineered nanomaterials (ENMs), Uptake, Trophic transfer, Food safety, Toxicity and impact doi: 10.1631 /jzus.A1400165

Document code: A

CLC number: X503

\section{Introduction}

Nanotechnology has revolutionized many facets of modern society through extensive application in the fields of material science, energy, environmental remediation, agriculture, and medicine. As this technology continues to expand, nano-scale materials will inevitably being discharged into the environment and have become emerging contaminants of concern. Importantly, the implications of nanotechnology for the environment and agriculture

\footnotetext{
Corresponding author

* Project supported by the US Department of Agriculture-Agriculture and Food Research Initiative (USDA-AFRI) (No. 2011-67006-30181) and the USDA-AFRI Hatch Program (No. MAS 00978)

(C) Zhejiang University and Springer-Verlag Berlin Heidelberg 2014
}

remain unclear; without this fundamental knowledge, development of regulations and guidelines for safe use of engineered nanomaterials (ENMs) will not be possible.

The dramatic increase in worldwide production and application of ENMs is due to novel and useful material properties that become evident at the nanoscale. On the scale of nanometers, the relatively large surface area of ENMs results in enhanced chemical/biological activity. In addition, quantum effects become significant with size reduction, subsequently changing particle optical, electrical, and magnetic behaviors. However, great variation exists among different ENMs, including size, shape, physical conformation, specific surface area, surface charge, and the presence of coatings/functionality (Hassellov et al., 2008; Parsons et al., 2010; Pan and 
Xing, 2012). From the perspective of nanobiological interactions, the most attractive ENMs traits include a high degree of surface reactivity and a size-dependent ability to cross biological membranes. Because ENMs will be on the same scale as the key components of cells, including proteins, nucleic acids, lipids, and cellular organelles, significant particle-cellular interactions (both positive and negative) can be anticipated (Fadeel et al., 2007; Auffan et al., 2009).

The widespread presence of ENMs in the environment will bring significant and unique challenges to food safety and security. The global production and application of ENMs make particle accumulation in soil and groundwater inevitable. Plant species exposed to ENMs over time may undergo morphological, physiological, genetic, and epigenetic changes that may subsequently affect crop growth, yield, or nutritional status. Furthermore, after ENM transfer from soil to the edible/ reproductive organs of crops, particles may accumulate in the food chain with unknown consequences to humans and other sensitive receptors. As such, consumption of food products from contaminated soil presents an unknown risk to public and environmental health.

There are many studies reporting the results of ENM toxicity tests conducted on model organisms and aquatic species such as Arabidopsis thaliana (Liu et al., 2010; Wang H. et al., 2011) and algae (He et al., 2012). These studies and others provide evidence of both beneficial and detrimental effects on plants upon ENMs exposure. However, the literature is far too anemic to shed light on the responses of edible terrestrial plants with regard to food safety and overall nanotechnology sustainability. In this review we summarize and interpret the literature on ENM-crop interactions so as to further efforts to achieve a comprehensive understanding of (1) the exposure conditions and scenarios of agricultural crops to ENMs in the environment; (2) the uptake pattern of ENMs internalization and translocation in vivo; (3) potential trophic transfer; and (4) the impact of ENMs on agricultural crops at morphological, physiological, and genetic/epigenetic levels. Based on this review, we will identify critical knowledge gaps and highlight future research priorities.

\section{Exposure scenarios}

\subsection{ENMs in real environments}

Although ENMs are ubiquitous in the environment, actual data measuring ENMs concentrations in various media is scarce (Klaine et al., 2008). Much of this is due to limited techniques for separation/ extraction, characterization, and quantitation of ENMs environmental samples. One group has predicted environmental ENMs concentrations through probabilistic material flow analysis (Mueller and Nowack, 2008; Gottschalk et al., 2009; 2013). As described in their work, the annual increase of ENMs in sludge amended EU or US soil was predicted to range from $1 \mathrm{ng} / \mathrm{kg}$ for fullerenes to $89 \mu \mathrm{g} / \mathrm{kg}$ for nano- $\mathrm{TiO}_{2}$ (Gottschalk et al., 2009). However, the predicted data are highly variable due to the poorly defined model inputs such as production volume and flow coefficients. Although ENMs concentrations in soils were reported or predicted to be low, these materials will accumulate over time in soils and rates may vary in response to unknown parameters (Boxall et al., 2007; Gottschalk et al., 2009). Research about potential risks of these particles should be completed before contamination or detrimental effects are observed. To achieve this goal, a solid data set of ENMs concentrations in environmental media is of critical importance. When ENMs are discharged into the environment, they can persist in air, water, and soil similar to naturally occurring nanoparticles. Crop roots could be exposed to ENMs in soils and irrigation water while the leaves and stems will be in direct contact with atmospheric ENMs. Crop growth in contaminated soils is an obvious major avenue of exposure, and soils could be contaminated through various intentional or accidental ENMs releases.

The main routes of entry for ENMs into agricultural fields include intentional application in agrichemicals to enhance crop protection, as well as through soil remediation efforts. Specific uses of ENMs in agrichemicals include incorporation into nanodevices as delivery system to specific target tissues, as additives in pesticides to increase solubility of active ingredients or to protect against premature active ingredient degradation (Gonzalez-Melendi et al., 2008; Baruah and Dutta, 2009; Kah et al., 2013; Kumari and Yadav, 2014). For example, farmers may use pesticides containing silver nanoparticles because 
of their capability to suppress the growth of harmful organisms (Bergeson, 2010). ENMs are also used to remediate contaminated soils; the most common example is nano-zero-valent iron (nZVI). The large surface area and high surface reactivity of nano $\mathrm{Fe}$ particles has proven effective at transforming and detoxifing a wide variety of common contaminants, including chlorinated organic solvents, organochlorine pesticides, and polychlorinated biphenyls (PCBs) (Zhang, 2003).

Accidental release or transport of ENMs from other media (water, air, soil amendments) into soil is also likely to occur. For instance, nano- $\mathrm{CeO}_{2}$ is added into commercial diesel fuel as combustion catalyst. A case study showed that cerium oxide concentrations were estimated to vary between 0.32 and $1.12 \mu \mathrm{g} / \mathrm{g}$ at a distance of $26 \mathrm{~m}$ from the edge of highway, and between 0.28 and $0.98 \mu \mathrm{g} / \mathrm{g}$ for a distance of $96 \mathrm{~m}$ away (Park et al., 2008). In addition, ENMs could be transported from water to soil. It was reported that the conventional drinking water treatment can only remove $2 \%-20 \%, 3 \%-8 \%$, and $48 \%-99 \%$ of $\mathrm{Ag}$, $\mathrm{TiO}_{2}$ and $\mathrm{ZnO}$ nanoparticles, respectively, and that nano-sized metals were still detectable in finished water (Chalew et al., 2013). Besides atmospheric deposition and ENMs persistence through water treatment, another important exposure pathway is through the application of biosolids on agricultural soils. Within the US, more than $60 \%$ of biosolids produced each year are added to agricultural fields (National Research Council Committee, 2002). ENMs released from biosolids may enter soils, subsequently interacting with crops and potentially affecting the quality, yield, and safety of food products.

\subsection{Laboratory designed exposure conditions}

The long-term growth of crops in ENMscontaminated soils is obviously the most environmentally relevant approach, but less complex systems (hydroponic, model media) under shorter exposure scenarios will be necessary to thoroughly characterize particle toxicity and accumulation mechanisms. For seed germination and seedling growth assays less than $7 \mathrm{~d}$, ENMs exposure solutions are typically prepared in water (Lin and Xing, 2007; Cifuentes et al., 2010; Lopez-Moreno et al., 2010a; Klancnik et al., 2011; Wang S. et al., 2011; Larue et al., 2012a). For hydroponic seedling growth assays with exposure intervals exceeding $7 \mathrm{~d}$, ENMs were more commonly suspended in nutrient media such as Hoagland's solution (Stampoulis et al., 2009; Castiglione et al., 2011; Musante and White, 2012; Wang et al., 2012). Homogeneous dispersions can be achieved by amendment with external surfactants or through the use of surface functionalized ENMs. For example, multi-wall carbon nanotubes (MWCNTs) and $\mathrm{C}_{70}$ fullerene were stabilized in natural organic matter (NOM, including humic acid) and gum Arabic solutions in the media (Lin et al., 2009; Larue et al., 2012b); metal-based ENMs such as $\mathrm{Fe}_{3} \mathrm{O}_{4}, \mathrm{Au}, \mathrm{Ag}$, and $\mathrm{Ni}(\mathrm{OH})_{2}$ were coated with citrate, tannate, or polyvinylpyrrolidone (PVP) (Parsons et al., 2010; Wang H. et al., 2011; Judy et al., 2012a; Lee et al., 2012). There are also reports using agar or semi-solid media such as Murashige and Skoog (MS) medium that may be amended with ENMs prior to solidification (Lee et al., 2008; 2012; Miralles et al., 2012b; Yang et al., 2012; Yan et al., 2013). In either agar or aqueous systems, biocompatible agents such as humic acid are preferable due to greater environmental relevance and less potential toxicity than synthetic surfactants such as sodium dodecyl sulfate (SDS) or PVP.

Semisolid media in petri dishes and hydroponics are simple systems, facilitating homogeneous mixing and immediate contact of ENMs with root surfaces; this experimental approach allows a focus on intrinsic particle properties. But from a practical and realistic perspective, soil-based studies are more relevant and important. Soil or similar porous materials can physically and chemically alter the stability and availability of ENMs to terrestrial biota, including plants. To date, the knowledge of ENMs-crop interactions in soil-based systems is very limited. In some published trials, sand or soil was either amended with nanomaterial powders or with ENMs suspensions (Du et al., 2011; Dimkpa et al., 2012; El-Temsah and Joner, 2012; Priester et al., 2012; Zhao et al., 2012a; 2012b; Khodakovskaya et al., 2013). A design with outdoor lysimeters under field condition was first introduced to investigate the impact of ENMs on Triticum aestivum (wheat) growth and soil enzyme activities; here, the topsoil was ex-situ amended with $\mathrm{TiO}_{2}$ and $\mathrm{ZnO}$ nanoparticles (Du et al., 2011). This type of research, although still limited in scope, provides important environmentally relevant information on the fate and 
bioavailability of ENMs in agricultural systems. Additional similar yet expanded studies will be needed to fully characterize the impact of ENMs on crop growth, uptake and potential particle trophic transfer.

It is also worth noting that some less intuitive routes of ENMs entry into aerial plant tissues have also been considered, including injection, leaf spray and atmospheric exposures (Corredor et al., 2009; Birbaum et al., 2010). Although leaves may possess resistant barriers, these studies will help to clarify all possible ENM exposure routes.

\section{Uptake of ENMs into agricultural crops}

Among terrestrial plant species, major agricultural crops raise obvious concerns due to their direct consumption as food. The crops that have been evaluated for ENMs accumulation and toxicity are numerous and include Triticum aestivum (wheat), Cucumis sativus (cucumber), Zea mays (corn), Allium cepa (onion), Cucurbita pepo/mixta (zucchini/ pumpkin), Lycopersicon esculentum (tomato), Oryza sativa (rice), Glycine max (soybean), Lactuca sativa (lettuce), and Nicotiana xanthi (tobacco). Among these species, Cucurbita pepo/mixta and Cucumis sativus are commonly used in uptake and translocation experiments due to their large-size vascular bundles and significant water uptake capacity. In terms of ENM detection in planta, magnetic and carbon-based nanoparticles can be detected in vivo by magnetic resonance imaging and radiolabeling, respectively. Additional complementary techniques to provide evidence for root or shoot uptake of ENMs, include (1) microscopic techniques, e.g., transmission electron microscopy (TEM), scanning electron microscopy (SEM), scanning X-ray fluorescence microscopy (XFM) and confocal laser scanning microscopy (CLSM), coupled with (2) other qualitative/ quantitative techniques, such as energy-dispersive spectroscopy (EDS), inductively coupled plasmamass spectrometry (ICP-MS), and Raman spectroscopy, and occasionally assisted with (3) isotope tracer or labeling techniques. Although viable techniques for ENM in planta detection, information is still far too limited to mechanistically characterize uptake processes conclusively. However, based on knowledge from the existing literature, some similar- ities and patterns in uptake process are evident and summarized below.

\subsection{Surface contamination and metal speciation}

When root surfaces are exposed in ENMscontaining media, these materials tend to accumulate on the epidermis or adhere onto surficial tissues as individual particles and/or aggregates (Lin and Xing, 2008; Wild and Jones, 2009; Zhao et al., 2012b). The initial contact or interaction may occur via electrostatic adsorption, mechanical adhesion or hydrophobic affinity of certain ENMs (Zhang H.F. et al., 2011). During accumulation experiments, it is critical to distinguish adsorption and actual ENMs uptake. In most uptake studies of metal-based ENMs, tap or deionized water is used to rinse the root surface, and then the whole tissue is digested for metal content determination. However, uptake data based on this type of procedure is really a semi-quantitative evaluation since a fraction of strongly adsorbed ENMs will be retained and digested with the tissues. Agents such as $\mathrm{NaOAc}$ and $\mathrm{Na}_{4} \mathrm{EDTA}$ may be used to remove adsorbed $\mathrm{CuO}$ nanoparticles from Triticum aestivum (wheat) root surface (Zhou et al., 2011). This amendment significantly facilitated $\mathrm{CuO}$ desorption from root surfaces without introducing new stress, presenting clear advantages over metal competing ions and surfactants. But the efficiency of removal was not widely tested among other ENMs and crop species, and it is not a standard approach when quantifying root uptake. When evaluating accumulation, data derived from aboveground tissues not in direct contact with exposure media is far more relevant. Moreover, it is necessary to include ion and bulk particle controls in experiments. Even so, multidisciplinary and orthogonal techniques should be applied to provide more accurate information, such as visualization via electron microscopy or metal speciation. Metal speciation is necessary not only because crops may accumulate dissolved ions instead of particles, but also it provides potential information on metal biotransformation in vivo. In addition, plant root exudates or biomass could potentially affect the dissolution and accumulation of metal-based ENMs. Some metal oxide nanoparticles undergo dissolution and their metal ions are subsequently accumulated by plants. It was also reported that Medicago sativa 
alfalfa shoot biomass was capable of reducing gold(III) to form gold(0) colloids in aqueous solutions and living alfalfa plants could uptake silver(I) and undergo nucleation to form silver nanoparticles (Gardea-Torresdey et al., 2000; 2003). As such, it becomes difficult to determine whether the metal species detected in plant tissues result from direct ion uptake or biotransformation within plant cells. While all $\mathrm{Au}$ remained as particles in plant shoots and $79 \%$ of $\mathrm{Ce}$ maintained the original $\mathrm{CeO}_{2}$ coordination, $\mathrm{CuO}$ ENMs accumulation by Triticum aestivum (wheat) shoot were in particulate $((64 \pm 10) \%)$ and complexed forms $(\mathrm{Cu}(\mathrm{I})$-sulfur complexes $((36 \pm 10) \%)) . \mathrm{ZnO}$ ENMs-exposed plants (Triticum aestivum, Glycine max) have $\mathrm{Zn}$ as $\mathrm{Zn}(\mathrm{II})$-phosphate or Zn-citrate complexes; no elemental particles were observed (Lopez-Moreno et al., 2010a; Judy et al., 2011; Dimkpa et al., 2012; 2013; Hernandez-Viezcas et al., 2013). This cursory review of the literature clearly suggests that observed phytotoxicity likely result from a combination of ion-driven and sizedependent effects.

\subsection{Processes of root uptake}

\subsubsection{Size-based selection by plant cell wall}

Plant cell walls are a complex matrix containing a network of cellulose microfibrils cross-linked with hemicellulose and lignin, and further impregnated by pectin (Serag et al., 2013). With this characteristic structure, root epidermal cell walls restrict the passage of large ENMs aggregates or agglomerates. Agglomerates are particles assemblages that could be fractured by considerable forces, while aggregates are a more definite pattern of prenucleation structures (Nichols et al., 2002). Cell wall pores are estimated to have sizes in a range of 5 to $20 \mathrm{~nm}$ (Carpita $e t$ al., 1979; Tepfer and Taylor, 1981); smaller clusters or individual particles could diffuse through pores and enter apoplastic and/or symplastic flow. In some instances, extensive ENMs sorption onto root surfaces could cause structural damage and compromise cell integrity. Also, carbon nanotubes may physically pierce epidermal and root hair cell walls (Wild and Jones, 2009), physically altering tissues in ways that may subsequently facilitate ENMs entry into the cellular cytoplasm.

\subsubsection{Apoplastic route}

When ENMs traverse porous cell walls, particles may diffuse in the space between the cell wall and plasma membrane: a route known as the apoplastic pathway and which is subject to osmotic pressure or capillary forces (Lin et al., 2009). Through the apoplast, particles may bypass epidermal and cortical cells to reach the endodermis. However, aggregates often accumulate in the endodermis as a result of the significant barrier imposed by the waxy Casparian strip (Larue et al., 2012a; Zhao et al., 2012b). For effective translocation to the shoot system, ENMs in apoplastic flow must eventually merge into the symplast so as to penetrate into vascular system, as presented in Fig. $1 b$.

\subsubsection{Symplastic route}

The symplastic route is hypothesized to be the more important and highly regulated pathway for transporting ENMs into crops. It has been proposed that cell internalization of ENMs could occur by binding to carrier proteins, through aquaporins, ion channels, endocytosis, or by creating new pores (carbon nanotubes) (Rico et al., 2011). While experimental data are scarce and many proposed mechanisms are under intense debate, endocytosis has been demonstrated definitively through the use of temperature control and the addition of endocytosisinhibiting agents such as wortmannin (Onelli et al., 2008; Liu et al., 2009; Iversen et al., 2012; Miralles et al., 2012b). Enhanced expression of aquaporin proteins and up-regulation of water channel genes were found to support possible passive uptake mechanisms (Khodakovskaya et al., 2012). Hydrophobic/ hydrophilic effect could also alter the interaction of ENMs with plant cell membranes. Hydrophobic nanomaterials tend to embeds into the hydrophobic core of the membrane without results in membrane leakage; while hydrophilic nanomaterials favor the adsorption on the surface of the bilayer, and they are more likely to bind to intracellular vesicles (Li et al., 2008; Stark, 2011). ENMs in the cytoplasm may be surrounded by protein or other biomolecules that form a corona ( $\mathrm{Nel}$ et al., 2009). Once within cells, the ENMs-containing endosomes or ENMs-protein complex could undergo efficient transport to neighboring cells via plasmodesmata, which typically have a diameter of $20-50 \mathrm{~nm}$. Notably, the structural 


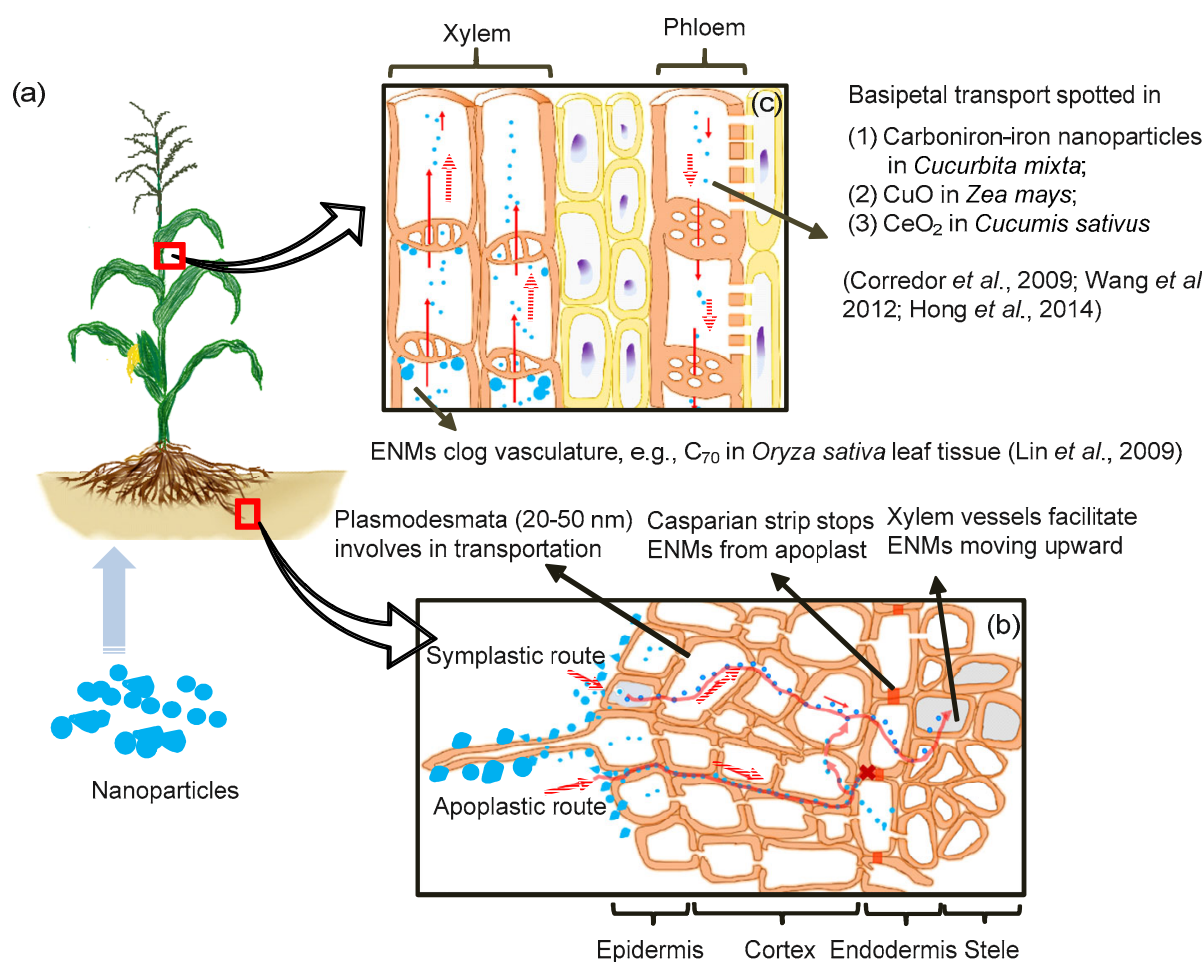

Fig. 1 Schematic diagram of uptake process and routes

(a) A model crop plant; (b) Root uptake processes and translocation into vasculature starting from root surface accumulation, symplastic/apoplastic flows into cortex and then traverses endodermis into xylem vessels; (c) Upward movement in xylem and downward transportation in phloem in both root and foliar uptake scenarios

integrity of plasmodesmata is maintained by cytoskeleton microfilaments and certain ENMs (ultrasmall $\mathrm{TiO}_{2}$ nanoparticles) have been reported to disrupt such microtubular networks in Arabidopsis thaliana (Wang S. et al., 2011; Larue et al., 2012a). Additionally, Rab proteins were hypothesized to have a role directing "cargo" to specific areas near plasmodesmata locations (Cifuentes et al., 2010). As a result, the transportation of ENMs may be facilitated through the normal and coordinated activity of organelles, transport proteins and trans-wall channels. Because of the high volume of material involved in symplastic flow, this pathway may prove to be highly effective at transporting ENMs through endodermis and into stele and subsequent vascular tissues.

\subsection{Foliar uptake}

As previously mentioned, foliar uptake was investigated in several studies that sought to characterize the possibility of phloem-based ENMs transport. ENMs have the potential to penetrate leaf surfaces through stomatal pores (Eichert et al., 2008; Larue et al., 2014). Basipetal translocation of carbon-coated iron nanoparticles was evident from the epidermis of exposed Cucurbita mixta petioles; similarly, Ce was found in Cucumis sativus roots after leaf exposure to nanoparticulate $\mathrm{CeO}_{2}$ (Corredor et al., 2009; Hong et al., 2014). Split-root experiments performed on Zea mays roots also indicated the movement of $\mathrm{CuO}$ from shoots to roots via phloem (Wang et al., 2012). Interestingly, in the above-mentioned study with $\mathrm{Cu}$ curbita mixta, ENMs aggregates were found to be present in "chains" of several adjacent parenchymatic cells oriented radially to the stem surface. Conversely, in root uptake studies, ENMs were found randomly distributed, suggesting that translocation through phloem may be more tightly regulated and organized than through xylem. Although experiments using atmospheric exposure are difficult, foliar uptake studies provide useful mechanistic information about ENMs distribution and translocation within crop plants.

\subsection{Translocation and distribution}

The in planta translocation and uptake of ENMs is a dynamic process that will depend on exposure 
conditions, ENMs properties, and crop species. Key characteristics of ENMs that will impact bioavailability/bioactivity include particle size, surface charge, affinity to water (hydrophilic/ hydrophobic), and protein/biomolecule adsorption. Upon accumulation, particle distribution via the vasculature (Fig. 1c) could occur rapidly; ENMs were detected in shoots as short as $24 \mathrm{~h}$ after carbon-coated magentic nanoparticle exposure to Helianthus annuus (sunflower), Lycopersicum sculentum (tomato), Pisum sativum (pea) and Triticum aestivum (wheat) (Cifuentes et al., 2010). An in vivo plant flow cytometry assessment showed that the average velocity of linear flow in Lycopersicum sculentum stems exposed to quantum dot-carbon nanotube conjugates was approximately $0.2 \mathrm{~mm} / \mathrm{s}$ (Nedosekin et al., 2011).

Various ENMs have been shown to translocate within stems, leaves, petioles, and fruits of different crops. Table 1 outlines a portion of the relevant literature, with a focus on transport to edible tissues. It is worth noting that all the listed studies present rather definitive evidence of ENMs transport, supported by direct visualization of ENMs or whole-plant mapping of ENMs signals. Based on these studies, some trends are evident: (1) Observable ENMs in shoots tend to be concentrated or restricted to locations near or within vascular tissues. This is likely a function of the transpiration flow/pattern through the leaf structure (Ghafariyan et al., 2013); (2) Small aggregates or individual particles are obviously more capable of long-range movement from root to subapical tissues, as compared to large aggregates from the same type of ENMs; (3) It is commonly found that leaf concentrations of ENMs are higher than that stems when expressed in amount per dry weight tissue; and (4) Separate from vascular transport, specific locations for ENMs distribution, such as the leaf periphery and trichomes, may be implicated in detoxifying pathways (Cifuentes et al., 2010). However, it is clear that large-scale patterns of in planta distribution are poorly understood. Unknown detoxification pathways may also confound assessment of ENM distribution within exposed plants.

Although multiple routes of ENMs translocation are possible, many ENMs will not transport to subapical tissues, with particle size being the primary reason for negligible accumulation. While $20 \mathrm{~nm}$ $\mathrm{Fe}_{3} \mathrm{O}_{4}$ was found to penetrate and move into Cucur- bita mixta (pumpkin), $25 \mathrm{~nm}$ did not translocate within the plants (Zhu et al., 2008; Wang H. et al., 2011). A study involving $\mathrm{nTiO}_{2}$ of different size (Anatase 14, 25, $140 \mathrm{~nm}$ and Rutile 22, 36, $655 \mathrm{~nm}$ ) concluded that ENMs with primary size under $36 \mathrm{~nm}$ could reach the stele in Triticum aestivum (wheat) roots whereas ENMs with sizes between 36-140 nm could only move to the root cortex. Another typical example is MWCNTs, which usually have lengths in the micrometer range. MWCNTs tended to adsorb onto root surfaces and pierce root epidermal tissue. The tubes induce physical damage and therefore stress crop plants without typically being internalized (Miralles et al., 2012a). Surface coating is a second important role in determining the possibility of ENMs uptake. As depicted above, ENMs may be surface-modified with biocompatible agents. These agents or surface functional groups have affinity with plasma membranes and significantly enhance ENMs uptake and translocation.

\section{Trophic transfer and potential risks to food safety}

Of particular concern is the internalization of ENMs into edible and reproductive tissues of plants; this has been shown for fullerol in fruits of Momordica charantia (Kole et al., 2013), fullerene $\left(\mathrm{C}_{70}\right)$ in Oryza sativa grains and second-generation seedlings (Lin et al., 2009), and MWCNTs in flowers of Lycopersicum sculentum (Khodakovskaya et al., 2013). In spite of these demonstrated phenomena, relevant research on ENM bioaccumulation and trophic transfer is poorly understood; a discussion of the limited published literature follows below.

Notably, the majority of existing data related to ENM trophic transfer come from studies in freshwater plants and aquatic invertebrates, e.g., transfer of quantum dots from ciliated protozoans to rotifers, $\mathrm{nTiO}_{2}$ from daphnia to zebrafish and quantum dots from dosed algae to C. dubia (Bouldin et al., 2008; Holbrook et al., 2008; Zhu et al., 2010). No biomagnification was observed in the above aquatic studies, with bioaccumulation factors (BAFs) ranging from 0.004-0.04 (Hou et al., 2013). However, research more related to agricultural systems points to the possibility of trophic transfer and biomagnification 
Table 1 Translocation and distribution of engineered nanomaterials in aerial tissues of agricultural crops through root uptake

\begin{tabular}{|c|c|c|c|c|c|c|c|}
\hline $\begin{array}{l}\text { Crop } \\
\text { name }\end{array}$ & $\begin{array}{l}\text { ENMs } \\
\text { type }\end{array}$ & $\begin{array}{l}\text { ENM } \\
\text { size }\end{array}$ & $\begin{array}{c}\text { Exposure } \\
\text { concentration } \\
\left(\times 10^{-6}\right)\end{array}$ & $\begin{array}{l}\text { Growth } \\
\text { matrix }\end{array}$ & $\begin{array}{l}\text { Location in } \\
\text { aboveground parts }\end{array}$ & $\begin{array}{l}\text { Accumulated } \\
\text { concentration }\end{array}$ & Reference \\
\hline $\begin{array}{l}\text { Bitter } \\
\text { melon }\end{array}$ & $\mathrm{C}_{60}(\mathrm{OH})_{20}$ & $\begin{array}{l}1.5 \pm 0.2 \mathrm{~nm} \\
5.0 \pm 0.7 \mathrm{~nm}\end{array}$ & $\begin{array}{l}1,5,10 \\
11.5,50\end{array}$ & $\begin{array}{l}\text { Germination in } \\
\text { aqueous media } \\
\text { for } 48 \mathrm{~h} \text { and } \\
\text { moved into soil }\end{array}$ & $\begin{array}{l}\text { Petioles, leaves, flowers, and } \\
\text { fruits }\end{array}$ & NA (not available) & $\begin{array}{l}\text { (Kole et al., } \\
\text { 2013) }\end{array}$ \\
\hline \multirow[t]{2}{*}{ Cucumber } & $\mathrm{CeO}_{2}$ & $7 \mathrm{~nm}$ & 20 & $\begin{array}{l}\text { Aqueous media } \\
\text { for } 10-14 d\end{array}$ & $\begin{array}{l}\text { Accumulated along leaf mar- } \\
\text { gins in young leaves; spread } \\
\text { all over the older leaves }\end{array}$ & $\begin{array}{l}162-550 \mathrm{ng} / \mathrm{g} \\
\text { (leaves); } \\
25.1-231.0 \mathrm{ng} / \mathrm{g} \\
\text { (stems) }\end{array}$ & $\begin{array}{l}\text { (Zhang Z.H. et } \\
\text { al., 2011) }\end{array}$ \\
\hline & & $25 \mathrm{~nm}$ & 20 & $\begin{array}{l}\text { Aqueous media } \\
\text { for } 10-14 \mathrm{~d}\end{array}$ & & $\begin{array}{l}33.7-383 \mathrm{ng} / \mathrm{g} \\
\text { (leaves); } 10.6-253 \\
\text { ng/g (stems) }\end{array}$ & \\
\hline Pea & Carbon-Fe & $10 \mathrm{~nm}$ & & $\begin{array}{l}\text { Aqueous media } \\
\text { for } 24-48 \mathrm{~h}\end{array}$ & $\begin{array}{l}\text { Observed in cortex, leaf peti- } \\
\text { oles, internodes; within and } \\
\text { outside vascular tissues }\end{array}$ & NA & $\begin{array}{l}\text { (Cifuentes et } \\
\text { al., 2010) }\end{array}$ \\
\hline Pumpkin & $\mathrm{Fe}_{3} \mathrm{O}_{4}$ & $20 \mathrm{~nm}$ & 500 & $\begin{array}{l}\text { Aqueous media } \\
\text { for } 20 \mathrm{~d}\end{array}$ & $\begin{array}{l}\text { Strong magnetic signals de- } \\
\text { tected in all leaf specimens } \\
\text { regardless of their distances } \\
\text { from the roots; much weaker } \\
\text { from the stem tissue samples } \\
\text { except those close to the roots }\end{array}$ & $\begin{array}{l}0.6 \% \text { of initial } \mathrm{Fe} \text { in } \\
\text { leaf tissues, } 45.4 \% \\
\text { in root tissues }\end{array}$ & (Zhu et al., \\
\hline Rapeseed & MWCNTs & $41.2 \mathrm{~nm}$ & 1000 & $\begin{array}{l}\text { Aqueous media } \\
\text { for } 7 \mathrm{~d}\end{array}$ & $\begin{array}{l}\text { Higher accumulation at periph- } \\
\text { eral areas of leaves; more ac- } \\
\text { cumulated in newly developed } \\
\text { leaves }\end{array}$ & $\begin{array}{l}\text { Transfer from sus- } \\
\text { pension to leaves } \\
\text { below } 0.005 \% \text { o }\end{array}$ & $\begin{array}{l}\text { (Larue et al., } \\
\text { 2012) }\end{array}$ \\
\hline Soybean & $\begin{array}{l}\text { SPIONs } \\
\left(\mathrm{FeO}_{x}\right)\end{array}$ & $9 \mathrm{nn}$ & 60 & $\begin{array}{l}\text { Aqueous media } \\
\text { for } 28 \mathrm{~d}\end{array}$ & $\begin{array}{l}\text { Diffused toward interior of the } \\
\text { stem parenchyma; detected in } \\
\text { stem and leaves, vascular and } \\
\text { parenchyma tissues }\end{array}$ & $\begin{array}{l}\text { TF (root to leaf) } \\
1.0 \% \text { for } \mathrm{SPIONs} \text {, } \\
1.4 \% \text { for } \mathrm{NH}_{2-} \\
\text { SPIONs and } 1.6 \% \\
\text { for COOH- } \\
\text { SPIONs }\end{array}$ & $\begin{array}{l}\text { (Ghafariyan } \\
\text { et al., 2013) }\end{array}$ \\
\hline Rice & $\mathrm{C}_{70}$ & $\begin{array}{l}1.19 \text { (major), } \\
17.99 \\
722.10 \mathrm{~nm}\end{array}$ & 20 & $\begin{array}{l}\text { Germination in } \\
\text { aqueous media } \\
\text { for } 14 \mathrm{~d} \text { and } \\
\text { moved in soil } \\
\text { for } 6 \mathrm{~mol}\end{array}$ & $\begin{array}{l}\text { Predominantly present in and } \\
\text { near the stem's vascular sys- } \\
\text { tem; in leaves; spotted in leaf } \\
\text { tissues of the second- } \\
\text { generation plants }\end{array}$ & NA & $\begin{array}{l}\text { (Lin et al., } \\
\text { 2009) }\end{array}$ \\
\hline Sunflower & Carbon-Fe & $10 \mathrm{~nm}$ & & $\begin{array}{l}\text { Aqueous media } \\
\text { for } 24-48 \mathrm{~h}\end{array}$ & $\begin{array}{l}\text { Observed in cortex, leaf peti- } \\
\text { oles, internodes; within and } \\
\text { outside vascular tissues }\end{array}$ & NA & $\begin{array}{l}\text { (Cifuentes et } \\
\text { al., 2010) }\end{array}$ \\
\hline Tobacco & $\mathrm{Au}$ & $10,30,50 \mathrm{~nm}$ & 30 & $\begin{array}{l}\text { Aqueous media } \\
\text { for } 7 \mathrm{~d}\end{array}$ & $\begin{array}{l}\text { Observed within leaf mid rib } \\
\text { near petiole }\end{array}$ & $\begin{array}{l}\text { Between } 2.2 \text { and } \\
53.5 \mathrm{mg} / \mathrm{kg} \text { in } \\
\text { aerial tissues }\end{array}$ & $\begin{array}{l}\text { (Judy et al., } \\
\text { 2012) }\end{array}$ \\
\hline \multirow[t]{3}{*}{ Tomato } & Carbon-Fe & $10 \mathrm{~nm}$ & & $\begin{array}{l}\text { Aqueous media } \\
\text { for } 24-48 \mathrm{~h}\end{array}$ & $\begin{array}{l}\text { Observed in cortex, leaf peti- } \\
\text { oles, internodes; within and } \\
\text { outside vascular tissues }\end{array}$ & NA & $\begin{array}{l}\text { (Cifuentes et } \\
a l ., 2010)\end{array}$ \\
\hline & MWCNTs & $25 \mathrm{~nm}$ & 50,200 & $\begin{array}{l}\text { Soil for 6-9 } \\
\text { weeks }\end{array}$ & $\begin{array}{l}\text { Clustered CNTs observed in the } \\
\text { flower structures }\end{array}$ & NA & $\begin{array}{l}\text { (Khodakovska- } \\
\text { ya } \text { et al., } \\
\text { 2013) }\end{array}$ \\
\hline & Carbon & $\begin{array}{c}10-35 \mathrm{~nm} \\
\text { (MWCNTs), } \\
0.86-2.22 \mathrm{~nm} \\
\text { (SWCNTs), } \\
2-5 \mathrm{~nm} \\
\text { (graphene) }\end{array}$ & 50 & $\begin{array}{l}\text { Agar MS me- } \\
\text { dium for } 10 \mathrm{~d}\end{array}$ & $\begin{array}{l}\text { Observed outside the leaves' } \\
\text { vascular system; randomly } \\
\text { among individual cells; only a } \\
\text { few were found in close } \\
\text { proximity to the leaf vascula- } \\
\text { tures }\end{array}$ & NA & $\begin{array}{l}\text { (Khodakovska- } \\
\text { ya et al., } \\
\text { 2011) }\end{array}$ \\
\hline \multirow[t]{2}{*}{ Wheat } & MWCNTs & $41.2 \mathrm{~nm}$ & 1000 & $\begin{array}{l}\text { Aqueous media } \\
\text { for } 7 \mathrm{~d}\end{array}$ & $\begin{array}{l}\text { Higher accumulation at periph- } \\
\text { eral areas of leaves; more ac- } \\
\text { cumulated in newly developed } \\
\text { leaves }\end{array}$ & NA & $\begin{array}{l}\text { (Larue et al., } \\
\text { 2012) }\end{array}$ \\
\hline & Carbon-Fe & $10 \mathrm{~nm}$ & & $\begin{array}{l}\text { Aqueous media } \\
\text { for } 24-48 \mathrm{~h}\end{array}$ & $\begin{array}{l}\text { Observed in cortex, leaf petio- } \\
\text { tles, internodes; within and } \\
\text { outside vascular tissues; } \\
\text { strongly accumulated in leaf } \\
\text { trichomes }\end{array}$ & NA & $\begin{array}{l}\text { (Cifuentes } \\
\text { et al., 2010) }\end{array}$ \\
\hline
\end{tabular}


through the food chain. One group working demonstrated BAFs of $6.2,11.6$, and 9.6 for tobacco hornworm consuming leaves of Nicotiana xanthi (tobacco) grown in 5, 10, and $15 \mathrm{~nm} \mathrm{Au}$ nanoparticles suspensions (Judy et al., 2012a). The authors later reported a much smaller BAF (0.16) for caterpillars consuming Lycopersicum sculentum leaves that were surface contaminated with Au nanoparticles (Judy et al., 2012b). Meanwhile, nano Au (20 or $55 \mathrm{~nm}$ ) can be taken up by earthworms (Eisenia fetida) from soil, and nano Au were found more bioavailable through trophic exposure (earthworms to bullfrogs (Rana catesbeina)) than direct exposure (bullfrogs to nano Au contaminated soils) (Unrine et al., 2010; 2012). These studies suggest that ENMs trophic exposure and biomagnification is possible and of concern in agriculture. The limited information and large knowledge gaps make accurate assessment of ENMs exposure and risk during trophic transfer impossible (Gardea-Torresdey et al., 2014); clearly, considerable work in this critical area is needed to enable food safety guidance and policy development.

\section{Impact on plants}

In addition to food safety concerns related to ENM accumulation, the quality and yield of agricultural crops may also be compromised by ENM exposure. The hypothesis that ENMs can affect crop growth has been tested repeatedly under a number of exposure scenarios. The effects of ENMs exposure can vary greatly, ranging from subtle changes in the soil environment to direct and overt phytotoxicity involving alternations in morphology, physiology, and gene expression. The final effect will also be impacted by species-specific defense systems in response to ENMs induced stress. In spite of some studies reporting ENMs beneficial effects on crop species, the negative effects on crops may well exceed possible advantages of ENMs application in agriculture, and more importantly, concerns on safety and quality of food products arise from the evidence of negative effects, which include growth inhibition in seeds/seedling stages, oxidative stress, altered photosynthesis, genetic damage, compromised agronomic and yield characteristics, and ENMs facilitated uptake with other soil contaminants.

\subsection{General toxicity tests on seeds/seedlings}

Although there are no established specific testing standard protocols for ENMs, US Environmental Protection Agency (EPA) and Organization for Economic Cooperation and Development (OECD) phytotoxicity guidelines are frequently used. Measured biological endpoints include germination index (time and rate), root elongation, shoot/root biomass, and root tip morphology. ENMs exposure concentrations are typically quite high, often approaching 1000 $4000 \mathrm{mg} / \mathrm{L}$. At these high levels, overt toxicity is frequently observed. For example, reduced germinated was noted with nanoparticle ZVI on Hordeum vulgare and Linum usitatissimum seeds at $250 \mathrm{mg} / \mathrm{L}$, $\mathrm{NP}-\mathrm{ZnO}$ on Zea mays seeds at $2000 \mathrm{mg} / \mathrm{L}$, and $\mathrm{CeO}_{2}$ on Medicago sativa, Zea mays and Cucumis sativus seeds at $2000 \mathrm{mg} / \mathrm{L}$ (Lin and Xing, 2007; LopezMoreno et al., 2010b; El-Temsah and Joner, 2012; Feizi et al., 2012; Ghafariyan et al., 2013). Compared to metal-based ENMs, CNTs were shown to not affect seed germination even at $2000 \mathrm{mg} / \mathrm{L}$ (Lin and Xing, 2007; Miralles et al., 2012a). Positive effects on seed germination were reported mainly in $\mathrm{TiO}_{2}$ and industrial-grade CNTs, particularly on seeds with inherently low germination (Zheng et al., 2005; Miralles et al., 2012a; Feizi et al., 2013). Thus, reactive oxygen species (ROS) induced by nano- $\mathrm{TiO}_{2}$ may have enhanced seed stress resistance and facilitated capsule penetration for water and oxygen intake that enabled more rapid germination (Khot et al., 2012). For industrial-grade CNTs, catalyst impurities, including $\mathrm{Fe}$ and $\mathrm{Al}_{2} \mathrm{O}_{3}$, can approach and exceed percent levels and as such, these materials rather than CNTs could enhance seed vigor by similar hormesis.

Compared to seed germination, root and shoot growth of seedlings is generally regarded as a more sensitive indicator of toxicity. Although exposure dose and duration vary significantly in the literature, negative effects on seedlings root/shoot elongation and biomass were noted for metal-based ENMs such as $\mathrm{ZnO}, \mathrm{CuO}, \mathrm{Ag}$, and $\mathrm{Al}_{2} \mathrm{O}_{3}$, largely due to toxicity from the enhanced release of ions from ENMs. However, positive effects were noticed upon NP Au, $\mathrm{Fe}_{2} \mathrm{O}_{3}, \mathrm{CeO}_{2}$ exposure over ion or bulk particle controls, including size-specific effects on root elongation (Barrena et al., 2009; Lopez-Moreno et al., 2010a; Ghodake et al., 2011; Dimkpa et al., 2012; Alidoust 


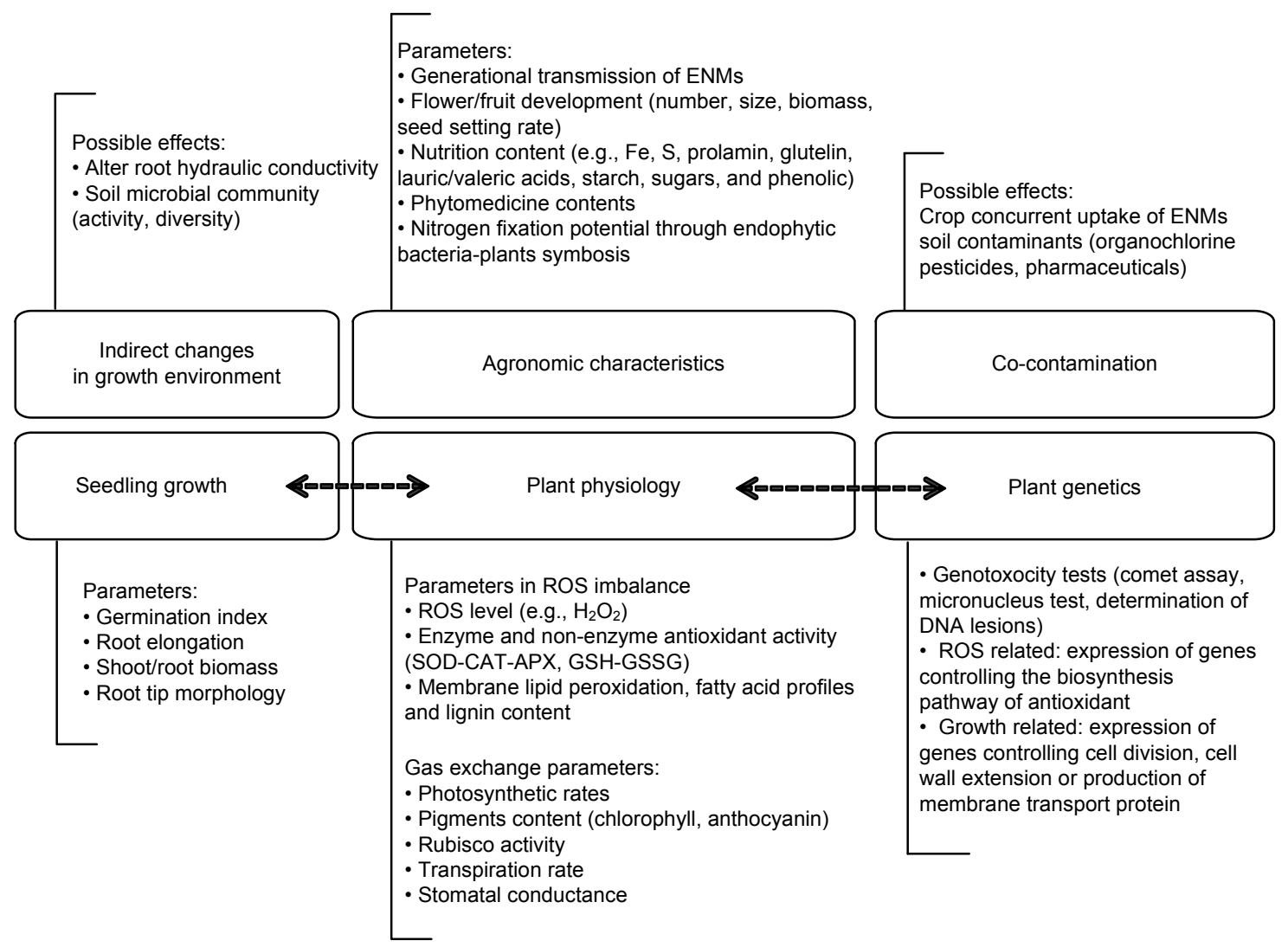

Fig. 2 An overview of ENMs impact on agricultural crops, including toxicity, growth performance, and physiological changes observed from seeds/seedlings stage to mature crop plants

and Isoda, 2013; Ghafariyan et al., 2013). Conflicting data in the literature are common for carbon-based ENMs such as graphene, SWCNTs, and MWCNTs (Canas et al., 2008; Begum et al., 2011; Miralles et al., 2012a). More disconcerting than the contradictory findings in the literature is the almost complete lack of mechanistic understanding for the observed plant responses.

\subsection{Physiological changes}

When compared to more generic growth parameters, physiological endpoints are potentially more informative with regard to the interactions between ENMs and crop species. The two most common physiological parameters involve the generation of (or effects from) ROS with related antioxidant defenses and various aspects of photosynthetic system function. ROS generation and oxidative stress were hypothesized to be the most likely paradigm for ENM phytotoxicity, largely due to the direct relationship between high reactive surface area and oxidative capability of these materials (Nel et al., 2006). Photosynthesis has been a focus due to its critical importance as an ecosystem service and its direct relationship to crop yield and quality; however, a mechanistic understanding here is generally lacking (Long et al., 2006).

\subsubsection{Oxidative stress and antioxidant enzymes}

ROS are by-products of aerobic metabolism, usually in reduced forms of $\mathrm{O}_{2}$ such as superoxide radical $\left(\mathrm{O}^{2-}\right)$, hydrogen peroxide $\left(\mathrm{H}_{2} \mathrm{O}_{2}\right)$, and hydroxyl radical $\left(\mathrm{HO}^{-}\right)$. These products are actively generated as signaling molecules during cellular homeostasis, and rapidly scavenged by antioxidant defense machinery prior to significant toxic effects (Mittler, 2002; Apel and Hirt, 2004). The antioxidant defense system includes enzymatic (superoxide dismutase (SOD); catalase (CAT); ascorbate peroxidase (APX); glutathione reductase (GR); monodehy- 
droascorbate reductase (MDHAR); dehydroascorbate reductase (DHAR); glutathione peroxidase (GPX); guaiacol peroxidase (GOPX), and glutathioneS-transferase (GST)) and non-enzymatic antioxidants (ascorbic acid (ASH); glutathione (GSH); oxidized glutathione (GSSG); phenolic compounds, alkaloids, non-protein amino acids and a-tocopherols) (Gill and Tuteja, 2010). Among the antioxidant defenses, enzymatic group of SOD-CAT-APX and non-enzymatic group of GSH-GSSG are typically most commonly evaluated.

An imbalance between production and scavenging can lead to an oxidative burst, a phenomenon commonly noted in stressed plants. Oxidative stress and over-accumulation of ROS will induce cell damage, e.g., membrane lipid peroxidation, protein oxidation, enzyme inhibition, DNA and RNA damage, or activate the programed cell death pathway (PCD). An early report on oxidative stress involved the interaction between $\mathrm{NP} \mathrm{Fe}_{3} \mathrm{O}_{4}$ and Cucurbita mixta, with the authors noting significantly higher levels of SOD and CAT along with enhanced lipid peroxidation in the root tissue (Wang H. et al., 2011). In another study focusing on graphene-exposed Brassica campestris (cabbage), Lycopersicon esculentum (tomato) and Amaranthus tricolor/lividus (red spinach), ROS production was found to be dose-dependent $(0,500$, $1000,2000 \mathrm{mg} / \mathrm{L}$ ) (Begurn et al., 2011). Conversely, nano $\mathrm{TiO}_{2}$ at 5,25 , and $50 \mathrm{mg} / \mathrm{L}$ did not alter any oxidative stress biomarkers in Vicia faba shoot (Foltete et al., 2011). In such cases, NP exposure may either not induce ROS production or may induce ROS levels that are well managed by antioxidant defenses. Dimkpa et al. (2012) investigated the oxidative stress of Triticum aestivum grown in $\mathrm{NP} \mathrm{CuO}$ or $\mathrm{ZnO}$ amended sand. Although lipid peroxidation, increased GSSG level in shoots, and higher peroxidase (POD)/CAT activity were noted, the magnitude ROS over-production and stress was not great. The increase of certain antioxidant enzymes or lipid peroxidation is consequence of ROS imbalance, which is does indirectly suggest initial ROS overproduction. Direct evidence such as quantitative measurement of ROS should be presented where possible, e.g., data using oxidatively sensitive probes 2',7'-dichlorofluorescein diacetate (DCFH-DA) and 3,3'-diaminobenzidine (DAB). Direct evidence of ROS overproduction can also be determined through measurement of antioxidant related gene expression levels (Begurn et al., 2011)). Dimkpa et al. (2012) also highlighted another important issue, which involves being able to distinguish between ion-induced and NP-dependent stresses. In this study, $\mathrm{Cu}$ detected in the shoots was in both NP and $\mathrm{Cu}(\mathrm{I})$-sulfide forms. It was noticed that the increased production of CAT/POD was also found in Triticum aestivum treated with $\mathrm{Cu}$ ion solution, which might support the view that oxidative stress was a function of $\mathrm{Cu}$ ions released from nanoparticles rather than the presence of nanoparticles or their aggregates themselves (Gajewska and Sklodowska, 2010).

Alternatively, Zhao et al. (2012b) investigated the stress response of $\mathrm{CeO}_{2}$ nanoparticles on soilgrown Zea mays, and provided a comprehensive assessment of stress-related parameters including $\mathrm{H}_{2} \mathrm{O}_{2}$, CAT and APX activity, heat shock protein 70 (HSP70), lipid peroxidation, and cell death. Importantly, timing was noted as a critical factor in detecting plant stress response. Over-production of $\mathrm{H}_{2} \mathrm{O}_{2}$ in shoots was observed at day 10 but levels then gradually decreased until day 20 , when overaccumulation was no longer evident. This timedependent response suggests an adaptive process for crops grown in ENMs-contaminated environments. Also, the timing of biological endpoint determination should be taken into consideration when comparing ENMs-crop interactions across particles and species.

ROS over-production is also reflected in membrane fatty acid profiles and lignin content. For example, fatty acid content in Oryza sativa roots was significantly altered by nano $\mathrm{CeO}_{2}$ treatments (Rico et al., 2013b). Plant lignin content was also reduced with increasing nano $\mathrm{CeO}_{2}$ dosage, likely due to the fact that the balance between peroxidase activity and $\mathrm{H}_{2} \mathrm{O}_{2}$ content has a regulatory role in lignin synthesis (Rico et al., 2013a).

\subsubsection{Photosynthesis and gas exchanges parameters}

The production and scavenging of ROS are closely related to photorespiration pathways, photosynthetic apparatus, and mitochondrial respiration. As a consequence of ENMs stress, it is possible that photosynthetic processes may be suppressed or adversely affected.

Initial studies on the impact of $\mathrm{NP}^{\mathrm{TiO}_{2}}$ on Spinacia oleracea (spinach) photosynthesis (Zheng et al., 
2005; Su et al., 2007; Yang et al., 2007) showed increased photosynthetic rates, greater chlorophyll formation, and higher Rubisco activity with exposure, although a mechanistic explanation was not offered. Other studies with different ENMs and crops revealed no differences in photosynthesis and gas exchange (net photosynthetic rate), transpiration, and stomatal conductance for $\mathrm{CeO}_{2}$-Zea mays, $\mathrm{TiO}_{2}$-Triticum aestivum, $\mathrm{TiO}_{2}$-Vicia faba or $\mathrm{Fe}_{2} \mathrm{O}_{3}$ nanoparticlesGlycine $\max$ (Foltete et al., 2011; Larue et al., 2012a; Zhao et al., 2012a; Ghafariyan et al., 2013). However, unaltered gas exchange parameters did not mean that plants were unaffected; in fact, photosynthetic pigments and enzymatic structures at different stages of the photosynthesis reaction were found to be more sensitive endpoints than overall photosynthetic rates. For example, chlorophyll a and b contents in Oryza sativa seedlings were significantly diminished with $\mathrm{CeO}_{2} \mathrm{NP}$ treatment, as well as with Triticum aestivum treated with $\mathrm{CuO}$ and $\mathrm{ZnO}$ NPs (Dimkpa et al., 2012; Rico et al., 2013c). Similar suppression was also observed in some microalgae, and it was speculated to be a result of shading effect of nanomaterials, which cannot explain the inhibitory in higher plants (Sadiq et al., 2011; Oukarroum et al., 2012).

\subsection{Genetic alternations and damage}

Perhaps the most accurate and informative means to assess plant response to ENMs exposure involves molecular analysis. In addition, genetic studies would also provide important information to support physiological or phenotypic observations. For instance, Zea mays treated with SWCNTs exhibited enhanced root growth, and accordingly, the expression of seminal root associated genes was increased (Yan et al., 2013). Similarly, it is of great interest to study the up- and down-regulation of antioxidantrelated genes in conjunction with the production of antioxidant parameters, but unfortunately, there are no sufficient studies with terrestrial crop species. In the model plant Arabidopsis thaliana L., the expression of genes controlling the glutathione (GSH) biosynthesis pathway was significantly altered, confirming the oxidative stress. Specifically, NP $\mathrm{In}_{2} \mathrm{O}_{3}$ exposure increased glutathione synthase (GS) transcript production by 3.8-4.6-fold whereas nano $\mathrm{CeO}_{2}$ yielded only a 2-fold increase (Ma et al., 2013). In addition, in Nicotiana xanthi cells treated with
MWCNTs, the expression of aquaporin (NtPIPl) gene, as well as marker genes for cell division $(C y c B)$ and cell wall extension (NtLRX1), were significantly up-regulated upon exposure. This data suggests that the enhanced growth of cells was directly related to water uptake and cell division (Khodakovskaya et al., 2012).

Additional genotoxicity tests include the comet assay and micronucleus test, both of which have been used extensively on plant protoplast and mammalian cell lines. Among crop species, the micronucleus test has been more commonly employed, such as on the root tips of Allium cepa. Chromosomal aberrations, sticky chromosomes, disturbed metaphase, and multiple chromosomal breaks of varying degrees were noted as soon as 3 to $24 \mathrm{~h}$ after ENMs exposure; a relationship of these effects to overall increased lipid peroxidation was proposed (Kumari et al., 2009; 2011; Ghosh et al., 2010; Castiglione et al., 2011; Foltete et al., 2011; Klancnik et al., 2011). Also, as a result of overproduced ROS and lipid peroxidation, genotoxicity of $\mathrm{CuO}$ exposure as measured by significant accumulation of oxidatively modified, mutagenic DNA lesions was described in Raphanus sativus (radish), Lolium perenne (perennial ryegrass), and Lolium rigidum (annual ryegrass), e.g., 7,8-dihydro-8-oxoguanine, 2,6-diamino-4-hydroxy-5-formamidopyrimidine, 4,6diamino-5-formamidopyrimidine (Atha et al., 2012). Additional studies focused on genetic and epigenetic endpoints as a function of ENMs exposure are clearly needed for terrestrial crop species so as to adequately guide food safety considerations.

\subsection{Impacts through subtle changes in growth media}

In addition to direct stress from ENMs, plant growth may also be affected by particle-induced changes in growth media. Although these changes are generally more subtle than direct stress effects, they cannot be ignored as a supplementary factor in plant response and as an input parameter for food safety risk assessment efforts.

Certain ENMs have been shown to extensively cover plant root surfaces; it is possible the reduced hydraulic movement between soil and roots would therefore induce symptoms of water stress. A study on Zea mays seedlings found that root hydraulic 
conductivity was reduced, likely resulting inhibition of leaf growth and transpiration (Asli and Neumann, 2009). Importantly, this effect was time-dependent and after 6 weeks, and no difference was evident between control and ENMs treatment. In this case, a more in-depth investigation into gene or protein expression would be informative. Another potentially important indirect impact may result from changes in the soil microbial community as a function of ENM exposure. Arbuscular mycorrhizal fungi (AMF) exposed to iron oxide nanoparticles had significantly reduced glomalin content and clover biomass due to compromised nutrient acquisition (Feng et al., 2013). However, in many cases, linking soil microbial activity or diversity to plant responses may be difficult. For example, different groups of microorganisms were found to increase or decrease in soil amended with MWCNTs, but the overall bacterial diversity did not change and the changes in soil microorganisms that did occur were not correlated with Lycopersicon esculentum growth (Khodakovskaya et al., 2013).

\subsection{Impact on agronomic and yield characteristics}

Much of the ENM phytotoxicity literature has focused on short-term exposure (seedlings/vegetative phase), but to fully characterize particle fate and effects, as well as implications for food safety, research must include studies conducted until full maturity/ harvest. Only under those conditions can the impacts of ENM exposure on fruit/grain production quantity and quality (nutrition) be adequately assessed. Specific endpoints should include growth parameters (number of flowers/fruit, fruit mass/size, seed mass/number) and nutritional traits (protein and amino acid content, oils and fatty acids, carotenoids and minerals). As mentioned above, molecular analysis tracking the expression of critical genes may also be highly instructive.

Lin et al. (2009) conducted on Oryza sativa exposed to $\mathrm{C}_{70}$, and showed aggregated ENMs in second-generation seedlings when the first generation was exposed only during germination. Transmission of nanomaterials to the progeny through seeds suggests the potential that ENMs may present a longerterm chronic exposure hazard to human and non-human receptors. Khodakovskaya et al. (2013) illustrated that Lycopersicon esculentum grown in soil amended with MWCNTs produced two times more flowers and therefore, induced significantly greater fruit development as compared to control plants and plants receiving activated carbon. The promotion in flowering and reproductive system performance was likely attributed to active expression of water channel protein (aquaporin) and up-regulation of aquaporin and related genes. Similar promotion in fruit yield was reported in Momordica charantia (bitter melon) treated with fullerol $\left[\mathrm{C}_{60}(\mathrm{OH})_{20}\right]$ (Kole et al., 2013). Furthermore, the contents of two anticancer and two antidiabetic phytomedicinals were significantly increased with fullerol treatment (Kole et al., 2013). Another study on Oryza sativa treated with MWCNTs and $\mathrm{C}_{70}$ presented contrary results. The flowering of rice plants was delayed at least one month and the seed setting rate was reduced by $4.6 \%$ and $10.5 \%$, with $\mathrm{C}_{70}$ and MWCNTs treatments, respectively (Lin et al., 2009). However, these studies are highly limited and the impact of ENM exposure on flowering and fruit development remains an important unanswered question.

The nutrition level of crops grown in ENMscontaminated soil may also be compromised. It was reported that Oryza sativa grains harvested from nano $\mathrm{CeO}_{2}$ exposed plants had lower content of $\mathrm{Fe}, \mathrm{S}$, prolamin, glutelin, lauric and valeric acids, and starch (Rico et al., 2013b). In a similar exposure setting, nano $\mathrm{CeO}_{2}$ decreased the Mo concentration in $\mathrm{Cu}$ cumis sativus fruit and also altered nonreducing sugars, phenolic content and fractionation of proteins (Zhao et al., 2014). These tests on nutritional content of ENMs-treated edible tissues suggest that ENMs would affect fruit flavor, antioxidant content, and nutrition levels, as well as growth performance. However, it is still not fully understood whether these changes in nutrition content are indicators of stress induced by ENMs. Given the potential widespread application of nanotechnology in agrichemicals and agriculture, resolution of this question remains a critical issue of concern.

Another noteworthy aspect of ENMs impact on crops regarding food production is through influence on endophytic bacteria-plants symbosis. In Glycine max (soybean), nitrogen fixation potential per nodule was also severely diminished at medium and high nano $\mathrm{CeO}_{2}$ treatments $(50,100 \mathrm{~g} / \mathrm{kg}$ soil), which are correlated to absent bacteroids in nodules (Priester et al., 2012). Similarly, nano $\mathrm{TiO}_{2}$ disrupted Rhizobium- 
legume symbiosis between Pisum sativum (peas) and $R$. leguminosarum $b v$ viciae 3841 by altering the wall structures of the infection thread in nitrogen-fixing nodules, and subsequently delayed nitrogen fixation (Fan et al., 2014). These two studies suggest that Legume nitrogen fixation is very sensitive to ENMs exposure and that yield may be compromised. Clearly, more research is required to understand the potential ENMs impacts on crops and their important symbiosis with endophytic bacteria.

\subsection{Impact on co-existing contaminants}

ENMs interaction with co-existing contaminants may have implications for the quality and safety of crops. ENMs in agricultural soils can possibly affect the bioavailability of other soil pollutants (e.g., heavy metals, organochlorine pesticides, pharmaceuticals). For instance, $\mathrm{C}_{60}$ significantly increased weathered chlordane uptake from soil by Lycopersicon esculentum or Glycine max whereas MWCNTs decreased chlordane and DDx accumulation in Cucurbita pepo, Zea mays, Lycopersicum sculentum, and Glycine max (De La Torre-Roche et al., 2012a; 2012b; 2013; Kelsey and White, 2013). Nanoparticle Ag was found to decrease the $\mathrm{p}, \mathrm{p}^{\prime}$-DDE content of Glycine max tissues more than bulk Ag (De La Torre-Roche et al., 2012b). Although pharmaceutical contaminants and heavy metals in soils are currently not extensively tested in co-contamination studies, it is likely the co-existence of ENMs would affect their bioavailability, posing an important food safety concern. The interactions of ENMs with other soil contaminants could be complex, including disruption in membrane integrity, increased/decreased expression in membrane transport proteins, interference with dissolved organic matter, and competition between ENMs and other nutrients/contaminants. The resulting implications for food safety could be far reaching, but the current level of knowledge is still insufficient.

\section{Perspectives and research priorities}

Because ENMs are transported and may accumulate in agricultural soils through multiple pathways (e.g., biosolid application, atmospheric fallouts, irrigation with recycled water), exposure to crops is likely, potentially resulting in accumulation with largely unknown impacts on growth and productivity. In terms of food safety, trophic transfer of ENMs from crops to humans remains a major concern. Transmission of ENMs through the food chain is possible, but will be dependent on particle ability to move across the soil-plant barrier and accumulate in edible tissues. Existing evidence of ENMs transfer in food chains is largely restricted to invertebrates in aquatic systems, although a small number of studies with select terrestrial invertebrates have been published, but the risk posed to humans consuming these food products is completely unknown. Meaningful and accurate health risk assessment of ENMs is dependent on a thorough understanding of material fate and effects, including ENMs concentrations in agricultural soil/water, crops and subsequent trophic levels, as well as potential transformation in vivo.

Two additional research focus areas with regard to ENMs-crop interactions are: (1) elucidation of underlying molecular mechanisms of interaction and (2) illustration of various environmental factors that affecting ENMs-crop interactions under realistic conditions. First, a mechanistic understanding of ENMs-crop interactions is elusive but will be critical to accurate ENM risk assessment. There are many questions to be resolved. As mentioned above, metalbased ENMs must be compared with appropriate ion and bulk material controls, to reveal actual instances of size-dependent toxicity. Another open question is how surface functionalization of ENMs would affect their fate in particle uptake and accumulation. It is possible that in vivo, ENMs surface functional groups could covalently bind to protein/DNA or lipophilic molecules within the membrane or cytoplasm (Stark, 2011; Maurer-Jones et al., 2013). Additional emphasis should be placed on molecular/genetic level investigations to discover factors mediating transport and stress response to ENMs in vivo. In addition, metabolomics and proteomics could be introduced as an approach to probe stress response, including monitoring changes in secondary-metabolite profiles under ENMs exposure. Second, considering the complexity of agroecosystems, the influence of various environmental factors on ENMs-crop interactions needs to be addressed. Agricultural soils involve complex abiotic and biotic components, including mineral/nutrient, water, NOM, microorganisms/ endophytic bacteria, soil invertebrates and co-existing 
contaminant. Among these environmental factors, NOM is of primary interest, because of its ability to dramatically stabilize ENMs in aqueous media and subsequently affect aggregation/mobility (Ghosh et al., 2008; Johnson et al., 2009). However, the impact of NOM on the bioavailability/phytotoxicity of ENMs has not been thoroughly evaluated. Similarly, the role of other environmental factors (root exudation, soil $\mathrm{pH}$, cations/ionic strength, microbial diversity) in ENMs-crop interactions is poorly understood. It is also of great importance to investigate how ENMs would affect crop plants uptake of other co-existing soil contaminants. Hence, investigations of ENMs-crop interactions should be conducted under conditions that approximate environmental factors in rhizosphere.

Currently, measurement techniques remain a major limitation for assessing ENM fate and transport, including interactions with agricultural species. Without appropriate instrumental analysis, efficient tracking of ENMs in vivo or in situ will be difficult and prone to error. Synchrotron-based microfocused $\mathrm{X}$-rayfluorescence $(\mu$-SXRF) with microX-ray absorption near-edge structure ( $\mu$-XANES) or microXray diffraction $(\mu-\mathrm{XRD})$ are currently the most powerful set of techniques used for a complete characterization of biological samples. Among the set of techniques, $\mu$-SXRF is very useful, allowing in situ mapping of nanoparticles with high sensitivity, negligible sample damage, and enable tuning of the incident energy as desired (Ma et al., 2011; Majumdar et al., 2012; Hernandez-Viezcas et al., 2013; Hummer and Rompel, 2013). Other promising advances include single particle inductively coupled plasma-mass spectrometry (spICP-MS), solid sampling highresolution-continuum source atomic absorption spectrometry (HR-CS AAS) and two-photon excitation microscopy (TPEM) (Wild and Jones, 2009; Feichtmeier and Leopold, 2013; Gray et al., 2013). However, the most advanced instrumentation platforms used for these types of studies are costly and of limited accessibility (Szakal et al., 2014). As such, a multidisciplinary and orthogonal approach is needed, including the development of new or hybridized measurement techniques, in order to promote the understanding of ENMs-crop interactions (GardeaTorresdey et al., 2014; Petersen et al., 2014).
Many details of ENMs-crop interactions remain poorly understood, including the possibility of ENMs transmission from crops to human beings, cocontamination effects of ENMs with other soil pollutants, the mechanisms in plant uptake and stress response, and environmental factors mediating these interaction processes. With such a limited knowledge in ENMs-crop interactions, the quality, quantity, and safety of food products from ENMs-containing environments are impossible to assess. An awareness of potential risks from growing crops in ENMscontaminated soils and with the development of novel measurement techniques will help to overcome these knowledge gaps.

\section{Reference}

Alidoust, D., Isoda, A., 2013. Effect of gamma $\mathrm{Fe}_{2} \mathrm{O}_{3}$ nanoparticles on photosynthetic characteristic of soybean (Glycine $\max$ (L.) Merr.): foliar spray versus soil amendment. Acta Physiologiae Plantarum, 35(12):33653375. [doi:10.1007/s11738-013-1369-8]

Apel, K., Hirt, H., 2004. Reactive oxygen species: metabolism, oxidative stress, and signal transduction. Annual Review of Plant Biology, 55(1):373-399. [doi:10.1146/annurev. arplant.55.031903.141701]

Asli, S., Neumann, P.M., 2009. Colloidal suspensions of clay or titanium dioxide nanoparticles can inhibit leaf growth and transpiration via physical effects on root water transport. Plant, Cell \& Environment, 32(5):577-584. [doi:10.1111/j.1365-3040.2009.01952.x]

Atha, D.H., Wang, H.H., Petersen, E.J., et al., 2012. Copper oxide nanoparticle mediated DNA damage in terrestrial plant models. Environmental Science \& Technology, 46(3):1819-1827. [doi:10.1021/es202660k]

Auffan, M., Rose, J., Bottero, J.Y., et al., 2009. Towards a definition of inorganic nanoparticles from an environmental, health and safety perspective. Nature Nanotechnology, 4(10):634-641. [doi:10.1038/nnano.2009.242]

Barrena, R., Casals, E., Colon, J., et al., 2009. Evaluation of the ecotoxicity of model nanoparticles. Chemosphere, 75(7):850-857. [doi:10.1016/j.chemosphere.2009.01. $078]$

Baruah, S., Dutta, J., 2009. Nanotechnology applications in pollution sensing and degradation in agriculture: a review. Environmental Chemistry Letters, 7(3):191-204. [doi:10. 1007/s10311-009-0228-8]

Begum, P., Ikhtiari, R., Fugetsu, B., 2011. Graphene phytotoxicity in the seedling stage of cabbage, tomato, red spinach, and lettuce. Carbon, 49(12):3907-3919. [doi:10. 1016/j.carbon.2011.05.029]

Bergeson, L.L., 2010. Nanosilver: US EPA's pesticide office considers how best to proceed. Environmental Quality Management, 19(3):79-85. [doi:10.1002/tqem.20255]

Birbaum, K., Brogioli, R., Schellenberg, M., et al., 2010. No 
evidence for cerium dioxide nanoparticle translocation in maize plants. Environmental Science \& Technology, 44(22):8718-8723. [doi:10.1021/es101685f]

Bouldin, J.L., Ingle, T.M., Sengupta, A., et al., 2008. Aqueous toxicity and food chain transfer of quantum Dots (TM) in freshwater algae and Ceriodaphnia dubia. Environmental Toxicology and Chemistry, 27(9):1958-1963. [doi:10. 1897/07-637.1]

Boxall, A.B., Tiede, K., Chaudhry, Q., 2007. Engineered nanomaterials in soils and water: how do they behave and could they pose a risk to human health? Nanomedicine, 2(6):919-927. [doi:10.2217/17435889.2.6.919]

Canas, J.E., Long, M.Q., Nations, S., et al., 2008. Effects of functionalized and nonfunctionalized single-walled carbon nanotubes on root elongation of select crop species. Environmental Toxicology and Chemistry, 27(9): 1922-1931. [doi:10.1897/08-117.1]

Carpita, N., Sabularse, D., Montezinos, D., et al., 1979. Determination of the pore-size of cell-walls of living plant-cells. Science, 205(4411):1144-1147. [doi:10.1126/ science.205.4411.1144]

Castiglione, M.R., Giorgetti, L., Geri, C., et al., 2011. The effects of nano- $\mathrm{TiO}_{2}$ on seed germination, development and mitosis of root tip cells of Vicia narbonensis L. and Zea mays L. Journal of Nanoparticle Research, 13(6): 2443-2449. [doi:10.1007/s11051-010-0135-8]

Chalew, T.E.A., Ajmani, G.S., Huang, H.O., Schwab, K.J., 2013. Evaluating nanoparticle breakthrough during drinking water treatment. Environmental Health Perspectives, 121(10):1161-1166. [doi:10.1289/ehp.130 6574]

Cifuentes, Z., Custardoy, L., De La Fuente, J.M., et al., 2010. Absorption and translocation to the aerial part of magnetic carbon-coated nanoparticles through the root of different crop plants. Journal of Nanobiotechnology, 8(26):1-8. [doi:10.1186/1477-3155-8-26]

Corredor, E., Testillano, P.S., Coronado, M.J., et al., 2009. Nanoparticle penetration and transport in living pumpkin plants: in situ subcellular identification. BMC Plant Biology, 9:45. [doi:10.1186/1471-2229-9-45]

De La Torre-Roche, R., Hawthorne, J., Deng, Y., et al., 2012a. Fullerene-enhanced accumulation of $\mathrm{p}, \mathrm{p}^{\prime}$-DDE in agricultural crop species. Environmental Science \& Technology, 46(17):9315-9323. [doi:10.1021/es30 1982w]

De La Torre-Roche, R., Hawthorne, J., Musante, C., et al., 2012b. Impact of Ag nanoparticle exposure on p,p'-DDE bioaccumulation by Cucurbita pepo (Zucchini) and Glycine max (Soybean). Environmental Science \& Technology, 47(2):718-725. [doi:10.1021/es3041829]

De La Torre-Roche, R., Hawthorne, J., Deng, Y.Q., et al., 2013. Multiwalled carbon nanotubes and $\mathrm{C}_{60}$ fullerenes differentially impact the accumulation of weathered pesticides in four agricultural plants. Environmental Science \& Technology, 47(21):12539-12547. [doi:10. 1021/es4034809]
Dimkpa, C.O., Latta, D.E., McLean, J.E., et al., 2013. Fate of $\mathrm{CuO}$ and $\mathrm{ZnO}$ nano- and microparticles in the plant environment. Environmental Science \& Technology, 47(9):4734-4742. [doi:10.1021/es304736y]

Dimkpa, C.O., McLean, J.E., Latta, D.E., et al., 2012. CuO and $\mathrm{ZnO}$ nanoparticles: phytotoxicity, metal speciation, and induction of oxidative stress in sand-grown wheat. Journal of Nanoparticle Research, 14(9):1125. [doi:10. 1007/s11051-012-1125-9]

Du, W.C., Sun, Y.Y., Ji, R., et al., 2011. $\mathrm{TiO}_{2}$ and $\mathrm{ZnO}$ nanoparticles negatively affect wheat growth and soil enzyme activities in agricultural soil. Journal of Environmental Monitoring, 13(4):822-828. [doi:10. 1039/c0em00611d]

Eichert, T., Kurtz, A., Steiner, U., et al., 2008. Size exclusion limits and lateral heterogeneity of the stomatal foliar uptake pathway for aqueous solutes and water-suspended nanoparticles. Physiologia Plantarum, 134(1):151-160. [doi:10.1111/j.1399-3054.2008.01135.x]

El-Temsah, Y.S., Joner, E.J., 2012. Impact of Fe and Ag nanoparticles on seed germination and differences in bioavailability during exposure in aqueous suspension and soil. Environmental Toxicology, 27(1):42-49. [doi:10. 1002/tox.20610]

Fadeel, B., Kagan, V., Krug, H., et al., 2007. There's plenty of room at the forum: potential risks and safety assessment of engineered nanomaterials. Nanotoxicology, 1(2):73-84. [doi:10.1080/17435390701565578]

Fan, R.M., Huang, Y.C., Grusak, M.A., et al., 2014. Effects of nano- $\mathrm{TiO}_{2}$ on the agronomically-relevant Rhizobiumlegume symbiosis. Science of The Total Environment, 466-467:503-512. [doi:10.1016/j.scitotenv.2013.07.032]

Feichtmeier, N., Leopold, K., 2013. Detection of silver nanoparticles in parsley by solid sampling highresolution-continuum source atomic absorption spectrometry. Analytical and Bioanalytical Chemistry, 406(16):3887-3894. [doi:10.1007/s00216-013-7510-0]

Feizi, H., Moghaddam, P.R., Shahtahmassebi, N., et al., 2012. Impact of bulk and nanosized titanium dioxide $\left(\mathrm{TiO}_{2}\right)$ on wheat seed germination and seedling growth. Biological Trace Element Research, 146(1):101-106. [doi:10.1007/ s12011-011-9222-7]

Feizi, H., Kamali, M., Jafari, L., et al., 2013. Phytotoxicity and stimulatory impacts of nanosized and bulk titanium dioxide on fennel (Foeniculum vulgare Mill). Chemosphere, 91(4):506-511. [doi:10.1016/j.chemosphere.2012.12. 012]

Feng, Y., Cui, X., He, S., et al., 2013. The role of metal nanoparticles in influencing arbuscular mycorrhizal fungi effects on plant growth. Environmental Science \& Technology, 47(16):9496-9504. [doi:10.1021/es402109n]

Foltete, A.S., Masfaraud, J.F., Bigorgne, E., et al., 2011. Environmental impact of sunscreen nanomaterials: ecotoxicity and genotoxicity of altered $\mathrm{TiO}_{2}$ nanocomposites on Vicia faba. Environmental Pollution, 159(10): 2515-2522. [doi:10.1016/j.envpol.2011.06.020] 
Gajewska, E., Sklodowska, M., 2010. Differential effect of equal copper, cadmium and nickel concentration on biochemical reactions in wheat seedlings. Ecotoxicology and Environmental Safety, 73(5):996-1003. [doi:10. 1016/j.ecoenv.2010.02.013]

Gardea-Torresdey, J.L., Tiemann, K.J., Gamez, G., et al., 2000. Reduction and accumulation of gold(III) by Medicago sativa alfalfa biomass: X-ray absorption spectroscopy, $\mathrm{pH}$, and temperature dependence. Environmental Science \& Technology, 34(20):4392-4396. [doi:10.1021/es991 $325 \mathrm{~m}]$

Gardea-Torresdey, J.L., Gomez, E., Peralta-Videa, J.R., et al., 2003. Alfalfa sprouts: a natural source for the synthesis of silver nanoparticles. Langmuir, 19(4):1357-1361. [doi:10. 1021/la020835i]

Gardea-Torresdey, J.L., Rico, C.M., White, J.C., 2014. Trophic transfer, transformation, and impact of engineered nanomaterials in terrestrial environments. Environmental Science \& Technology, 48(5):2526-2540. [doi:10.1021/ es4050665]

Ghafariyan, M.H., Malakouti, M.J., Dadpour, M.R., et al., 2013. Effects of magnetite nanoparticles on soybean chlorophyll. Environmental Science \& Technology, 47(18):10645-10652. [doi:10.1021/es402249b]

Ghodake, G., Seo, Y.D., Lee, D.S., 2011. Hazardous phytotoxic nature of cobalt and zinc oxide nanoparticles assessed using Allium cepa. Journal of Hazardous Materials, 186(1):952-955. [doi:10.1016/j.jhazmat.2010.11.018]

Ghosh, M., Bandyopadhyay, M., Mukherjee, A., 2010. Genotoxicity of titanium dioxide $\left(\mathrm{TiO}_{2}\right)$ nanoparticles at two trophic levels: plant and human lymphocytes. Chemosphere, 81(10):1253-1262. [doi:10.1016/j. chemosphere.2010.09.022]

Ghosh, S., Mashayekhi, H., Pan, B., et al., 2008. Colloidal behavior of aluminum oxide nanoparticles as affected by $\mathrm{pH}$ and natural organic matter. Langmuir, 24(21): 12385-12391. [doi:10.1021/la802015f]

Gill, S.S., Tuteja, N., 2010. Reactive oxygen species and antioxidant machinery in abiotic stress tolerance in crop plants. Plant Physiology and Biochemistry, 48(12): 909-930. [doi:10.1016/j.plaphy.2010.08.016]

Gonzalez-Melendi, P., Fernandez-Pacheco, R., Coronado, M.J., et al., 2008. Nanoparticles as smart treatment-delivery systems in plants: assessment of different techniques of microscopy for their visualization in plant tissues. Annals of Botany, 101(1):187-195. [doi:10.1093/aob/mcm283]

Gottschalk, F., Sonderer, T., Scholz, R.W., et al., 2009. Modeled environmental concentrations of engineered nanomaterials $\left(\mathrm{TiO}_{2}, \mathrm{ZnO}, \mathrm{Ag}, \mathrm{CNT}\right.$, fullerenes) for different regions. Environmental Science \& Technology, 43(24):9216-9222. [doi:10.1021/es9015553]

Gottschalk, F., Sun, T.Y., Nowack, B., 2013. Environmental concentrations of engineered nanomaterials: review of modeling and analytical studies. Environmental Pollution, 181:287-300. [doi:10.1016/j.envpol.2013.06.003]

Gray, E.P., Coleman, J.G., Bednar, A.J., et al., 2013. Extraction and analysis of silver and gold nanoparticles from biological tissues using single particle inductively coupled plasma mass spectrometry. Environmental Science \& Technology, 47(24):14315-14323. [doi:10.1021/es40 $3558 \mathrm{c}]$

Hassellov, M., Readman, J.W., Ranville, J.F., Tiede, K., 2008. Nanoparticle analysis and characterization methodologies in environmental risk assessment of engineered nanoparticles. Ecotoxicology, 17(5):344-361. [doi:10. 1007/s10646-008-0225-x]

He, D., Dorantes-Aranda, J.J., Waite, T.D., 2012. Silver nanoparticle-algae interactions: oxidative dissolution, reactive oxygen species generation and synergistic toxic effects. Environmental Science \& Technology, 46(16): 8731-8738. [doi:10.1021/es300588a]

Hernandez-Viezcas, J.A., Castillo-Michel, H., Andrews, J.C., et al., 2013. In situ synchrotron X-ray fluorescence mapping and speciation of $\mathrm{CeO}_{2}$ and $\mathrm{ZnO}$ nanoparticles in soil cultivated soybean (Glycine max). ACS Nano, 7(2): 1415-1423. [doi:10.1021/nn305196q]

Holbrook, R.D., Murphy, K.E., Morrow, J.B., et al., 2008. Trophic transfer of nanoparticles in a simplified invertebrate food web. Nature Nanotechnology, 3(6): 352-355. [doi:10.1038/nnano.2008.110]

Hong, J., Peralta-Videa, J.R., Rico, C., et al., 2014. Evidence of translocation and physiological impacts of foliar applied $\mathrm{CeO}_{2}$ nanoparticles on cucumber (Cucumis sativus) plants. Environmental Science \& Technology, 48(8):4376-4385. [doi:10.1021/es404931g]

Hou, W.C., Westerhoff, P., Posner, J.D., 2013. Biological accumulation of engineered nanomaterials: a review of current knowledge. Environmental Science: Processes \& Impacts, 15(1):103-122. [doi:10.1039/c2em30686g]

Hummer, A.A., Rompel, A., 2013. The use of X-ray absorption and synchrotron based micro-X-ray fluorescence spectroscopy to investigate anti-cancer metal compounds in vivo and in vitro. Metallomics, 5(6):597-614. [doi:10. 1039/c3mt20261e]

Iversen, T.G., Frerker, N., Sandvig, K., 2012. Uptake of ricinB-quantum dot nanoparticles by a macropinocytosislike mechanism. Journal of Nanobiotechnology, 10:33. [doi:10.1186/1477-3155-10-33]

Johnson, R.L., Johnson, G.O., Nurmi, J.T., et al., 2009. Natural organic matter enhanced mobility of nano zerovalent iron. Environmental Science \& Technology, 43(14):5455-5460. [doi:10.1021/es900474f]

Judy, J.D., Unrine, J.M., Bertsch, P.M., 2011. Evidence for biomagnification of gold nanoparticles within a terrestrial food chain. Environmental Science \& Technology, 45(2): 776-781. [doi:10.1021/es103031a]

Judy, J.D., Unrine, J.M., Rao, W., et al., 2012a. Bioavailability of gold nanomaterials to plants: importance of particle size and surface coating. Environmental Science \& Technology, 46(15):8467-8474. [doi:10.1021/es3019397]

Judy, J.D., Unrine, J.M., Rao, W., et al., 2012b. Bioaccumulation of gold nanomaterials by Manduca sexta through 
dietary uptake of surface contaminated plant tissue. Environmental Science \& Technology, 46(22):1267212678. [doi:10.1021/es303333w]

Kah, M., Beulke, S., Tiede, K., Hofmann, T., 2013. Nanopesticides: state of knowledge, environmental fate, and exposure modeling. Critical Reviews in Environmental Science and Technology, 43(16):1823-1867. [doi:10. 1080/10643389.2012.671750]

Kelsey, J.W., White, J.C., 2013. Effect of $\mathrm{C}_{60}$ fullerenes on the accumulation of weathered $\mathrm{p}, \mathrm{p}^{\prime}$-DDE by plant and earthworm species under single and multispecies conditions. Environmental Toxicology and Chemistry, 32(5):1117-1123. [doi:10.1002/etc.2158]

Khodakovskaya, M.V., de Silva, K., Nedosekin, D.A., et al., 2011. Complex genetic, photothermal, and photoacoustic analysis of nanoparticle-plant interactions. Proceedings of the National Academy of Sciences of the United States of America, 108(3):1028-1033. [doi:10.1073/pnas. 1008856108]

Khodakovskaya, M.V., de Silva, K., Biris, A.S., et al., 2012. Carbon nanotubes induce growth enhancement of tobacco cells. ACS Nano, 6(3):2128-2135. [doi:10.1021/nn204 $643 \mathrm{~g}]$

Khodakovskaya, M.V., Kim, B.S., Kim, J.N., et al., 2013. Carbon nanotubes as plant growth regulators: effects on tomato growth, reproductive system, and soil microbial community. Small, 9(1):115-123. [doi:10.1002/smll. 201201225]

Khot, L.R., Sankaran, S., Maja, J.M., et al., 2012. Applications of nanomaterials in agricultural production and crop protection: A review. Crop Protection, 35:64-70. [doi:10. 1016/j.cropro.2012.01.007]

Klaine, S.J., Alvarez, P.J.J., Batley, G.E., et al., 2008. Nanomaterials in the environment: behavior, fate, bioavailability, and effects. Environmental Toxicology and Chemistry, 27(9):1825-1851. [doi:10.1897/08- 090.1]

Klancnik, K., Drobne, D., Valant, J., Koce, J.D., 2011. Use of a modified Allium test with nanoTiO ${ }_{2}$. Ecotoxicology and Environmental Safety, 74(1):85-92. [doi:10.1016/j. ecoenv.2010.09.001]

Kole, C., Kole, P., Randunu, K.M., et al., 2013. Nanobiotechnology can boost crop production and quality: first evidence from increased plant biomass, fruit yield and phytomedicine content in bitter melon (Momordica charantia). BMC Biotechnology, 13(1):37. [doi:10.1186/ 1472-6750-13-37]

Kumari, A., Yadav, S.K., 2014. Nanotechnology in agri-food sector. Critical Reviews in Food Science and Nutrition, 54(8):975-984. [doi:10.1080/10408398.2011.621095]

Kumari, M., Mukherjee, A., Chandrasekaran, N., 2009. Genotoxicity of silver nanoparticles in Allium cepa. Science of The Total Environment, 407(19):5243-5246. [doi:10.1016/j.scitotenv.2009.06.024]

Kumari, M., Khan, S.S., Pakrashi, S., et al., 2011. Cytogenetic and genotoxic effects of zinc oxide nanoparticles on root cells of Allium cepa. Journal of Hazardous Materials,
190(1-3):613-621. [doi:10.1016/j.jhazmat.2011.03.095]

Larue, C., Laurette, J., Herlin-Boime, N., et al., 2012a. Accumulation, translocation and impact of $\mathrm{TiO}_{2}$ nanoparticles in wheat (Triticum aestivum spp.): influence of diameter and crystal phase. Science of The Total Environment, 431:197-208. [doi:10.1016/j.scitotenv.2012.04. 073]

Larue, C., Pinault, M., Czarny, B., et al., 2012b. Quantitative evaluation of multi-walled carbon nanotube uptake in wheat and rapeseed. Journal of Hazardous Materials, 227-228:155-163. [doi:10.1016/j.jhazmat.2012.05.033]

Larue, C., Castillo-Michel, H., Sobanska, S., et al., 2014. Foliar exposure of the crop Lactuca sativa to silver nanoparticles: evidence for internalization and changes in $\mathrm{Ag}$ speciation. Journal of Hazardous Materials, 264: 98-106. [doi:10.1016/j.jhazmat.2013.10.053]

Lee, W.M., An, Y.J., Yoon, H., et al., 2008. Toxicity and bioavailability of copper nanoparticles to the terrestrial plants mung bean (Phaseolus radiatus) and wheat (Triticum aestivum): Plant agar test for water-insoluble nanoparticles. Environmental Toxicology and Chemistry, 27(9):1915-1921. [doi:10.1897/07-481.1]

Lee, W.M., Kwak, J.I., An, Y.J., 2012. Effect of silver nanoparticles in crop plants Phaseolus radiatus and Sorghum bicolor: Media effect on phytotoxicity. Chemosphere, 86(5):491-499. [doi:10.1016/j.chemosphere.2011.10. 013]

Li, Y., Chen, X., Gu, N., 2008. Computational investigation of interaction between nanoparticles and membranes: hydrophobic/hydrophilic effect. The Journal of Physical Chemistry B, 112(51):16647-16653. [doi:10.1021/ jp8051906]

Lin, D.H., Xing, B.S., 2007. Phytotoxicity of nanoparticles: Inhibition of seed germination and root growth. Environmental Pollution, 150(2):243-250. [doi:10.1016/ j.envpol.2007.01.016]

Lin, D.H., Xing, B.S., 2008. Root uptake and phytotoxicity of $\mathrm{ZnO}$ nanoparticles. Environmental Science \& Technology, 42(15):5580-5585. [doi:10.1021/es800422x]

Lin, S.J., Reppert, J., Hu, Q., et al., 2009. Uptake, translocation, and transmission of carbon nanomaterials in rice plants. Small, 5(10):1128-1132. [doi:10.1002/smll.200801556]

Liu, Q., Zhao, Y., Wan, Y., et al., 2010. Study of the inhibitory effect of water-soluble fullerenes on plant growth at the cellular level. ACS Nano, 4(10):5743-5748. [doi:10. 1021/nn101430g]

Liu, Q.L., Chen, B., Wang, Q.L., et al., 2009. Carbon nanotubes as molecular transporters for walled plant cells. Nano Letters, 9(3):1007-1010. [doi:10.1021/n1803083u]

Long, S.P., Zhu, X.G., Naidu, S.L., et al., 2006. Can improvement in photosynthesis increase crop yields? Plant, Cell \& Environment, 29(3):315-330. [doi:10.1111/j. 1365-3040.2005.01493.x]

Lopez-Moreno, M.L., De La Rosa, G., Hernandez-Viezcas, J.A., et al., 2010a. Evidence of the differential 
biotransformation and genotoxicity of $\mathrm{ZnO}$ and $\mathrm{CeO}_{2}$ nanoparticles on soybean (Glycine max) plants. Environmental Science \& Technology, 44(19):7315-7320. [doi:10.1021/ es903891g]

Lopez-Moreno, M.L., De La Rosa, G., Hernandez-Viezcas, J.A., et al., 2010b. X-ray absorption spectroscopy (XAS) corroboration of the uptake and storage of $\mathrm{CeO}_{2}$ nanoparticles and assessment of their differential toxicity in four edible plant species. Journal of Agricultural and Food Chemistry, 58(6):3689-3693. [doi:10.1021/ jf904472e]

Ma, C., Chhikara, S., Xing, B., et al., 2013. Physiological and molecular response of Arabidopsis thaliana (L.) to nanoparticle cerium and indium oxide exposure. ACS Sustainable Chemistry \& Engineering, 1(7):768-778. [doi:10.1021/sc400098h]

Ma, Y.H., He, X., Zhang, P., et al., 2011. Phytotoxicity and biotransformation of $\mathrm{La}_{2} \mathrm{O}_{3}$ nanoparticles in a terrestrial plant cucumber (Cucumis sativus). Nanotoxicology, 5(4): 743-753. [doi:10.3109/17435390.2010.545487]

Majumdar, S., Peralta-Videa, J.R., Castillo-Michel, H., et al., 2012. Applications of synchrotron $\mu-X R F$ to study the distribution of biologically important elements in different environmental matrices: a review. Analytica Chimica Acta, 755(0):1-16. [doi:10.1016/j.aca.2012.09. 050]

Maurer-Jones, M.A., Gunsolus, I.L., Murphy, C.J., et al., 2013. Toxicity of engineered nanoparticles in the environment. Analytical Chemistry, 85(6):3036-3049. [doi:10.1021/ ac303636s]

Miralles, P., Johnson, E., Church, T.L., et al., 2012a. Multiwalled carbon nanotubes in alfalfa and wheat: toxicology and uptake. Journal of the Royal Society Interface, 9(77):3514-3527. [doi:10.1098/rsif.2012. 0535]

Miralles, P., Church, T.L., Harris, A.T., 2012b. Toxicity, uptake, and translocation of engineered nanomaterials in vascular plants. Environmental Science \& Technology, 46(17): 9224-9239. [doi:10.1021/es202995d]

Mittler, R., 2002. Oxidative stress, antioxidants and stress tolerance. Trends in Plant Science, 7(9):405-410. [doi:10. 1016/S1360-1385(02)02312-9]

Mueller, N.C., Nowack, B., 2008. Exposure modeling of engineered nanoparticles in the environment. Environmental Science \& Technology, 42(12):4447-4453. [doi:10. 1021/es7029637]

Musante, C., White, J.C., 2012. Toxicity of silver and copper to Cucurbita pepo: differential effects of nano and bulk-size particles. Environmental Toxicology, 27(9):510-517. [doi:10.1002/tox.20667]

National Research Council Committee, 2002. National Research Council Committee on Toxicants Pathogens in Biosolids Applied to Land: Advancing Standards and Practices. National Academy Press.

Nedosekin, D.A., Khodakovskaya, M.V., Biris, A.S., et al., 2011. In vivo plant flow cytometry: a first proof-of- concept. Cytometry Part A, 79A(10):855-865. [doi:10. 1002/cyto.a.21128]

Nel, A., Xia, T., Madler, L., Li, N., 2006. Toxic potential of materials at the nanolevel. Science, 311(5761):622-627. [doi:10.1126/science.1114397]

Nel, A.E., Madler, L., Velegol, D., et al., 2009. Understanding biophysicochemical interactions at the nano-bio interface. Nature Materials, 8(7):543-557. [doi:10.1038/nmat2442]

Nichols, G., Byard, S., Bloxham, M.J., et al., 2002. A review of the terms agglomerate and aggregate with a recommendation for nomenclature used in powder and particle characterization. Journal of Pharmaceutical Sciences, 91(10):2103-2109. [doi:10.1002/jps.10191]

Onelli, E., Prescianotto-Baschong, C., Caccianiga, M., et al., 2008. Clathrin-dependent and independent endocytic pathways in tobacco protoplasts revealed by labelling with charged nanogold. Journal of Experimental Botany, 59(11):3051-3068. [doi:10.1093/jxb/ern154]

Oukarroum, A., Bras, S., Perreault, F., et al., 2012. Inhibitory effects of silver nanoparticles in two green algae, Chlorella vulgaris and Dunaliella tertiolecta. Ecotoxicology and Environmental Safety, 78:80-85. [doi:10.1016/j. ecoenv.2011.11.012]

Pan, B., Xing, B.S., 2012. Applications and implications of manufactured nanoparticles in soils: a review. European Journal of Soil Science, 63(4):437-456. [doi:10.1111/ j.1365-2389.2012.01475.x]

Park, B., Donaldson, K., Duffin, R., et al., 2008. Hazard and risk assessment of a nanoparticulate cerium oxide-based diesel fuel additive-a case study. Inhalation Toxicology, 20(6):547-566. [doi:10.1080/08958370801915309]

Parsons, J.G., Lopez, M.L., Gonzalez, C.M., et al., 2010. Toxicity and biotransformation of uncoated and coated nickel hydroxide nanoparticles on mesquite plants. Environmental Toxicology and Chemistry, 29(5):11461154. [doi:10.1002/etc.146]

Petersen, E.J., Henry, T.B., Zhao, J., et al., 2014. Identification and avoidance of potential artifacts and misinterpretations in nanomaterial ecotoxicity measurements. Environmental Science \& Technology, 48(8):4226-4246. [doi:10. 1021/es4052999]

Priester, J.H., Ge, Y., Mielke, R.E., et al., 2012. Soybean susceptibility to manufactured nanomaterials with evidence for food quality and soil fertility interruption. Proceedings of the National Academy of Sciences of the United States of America, 109(37):E2451-E2456. [doi:10. 1073/pnas.1205431109]

Rico, C.M., Majumdar, S., Duarte-Gardea, M., et al., 2011. Interaction of nanoparticles with edible plants and their possible implications in the food chain. Journal of Agricultural and Food Chemistry, 59(8):3485-3498. [doi:10.1021/jf104517j]

Rico, C.M., Morales, M.I., McCreary, R., et al., 2013a. Cerium oxide nanoparticles modify the antioxidative stress enzyme activities and macromolecule composition in rice seedlings. Environmental Science \& Technology, 47(24): 
14110-14118. [doi:10.1021/es4033887]

Rico, C.M., Morales, M.I., Barrios, A.C., et al., 2013b. Effect of cerium oxide nanoparticles on the quality of rice (Oryza sativa L.) grains. Journal of Agricultural and Food Chemistry, 61(47):11278-11285. [doi:10.1021/ jf404046v]

Rico, C.M., Hong, J., Morales, M.I., et al., 2013c. Effect of cerium oxide nanoparticles on rice: A study involving the antioxidant defense system and in vivo fluorescence imaging. Environmental Science \& Technology, 47(11): 5635-5642. [doi:10.1021/es401032m]

Sadiq, I.M., Pakrashi, S., Chandrasekaran, N., Mukherjee, A., 2011. Studies on toxicity of aluminum oxide $\left(\mathrm{Al}_{2} \mathrm{O}_{3}\right)$ nanoparticles to microalgae species: Scenedesmus sp. and Chlorella sp. Journal of Nanoparticle Research, 13(8): 3287-3299. [doi:10.1007/s11051-011-0243-0]

Serag, M.F., Kaji, N., Habuchi, S., et al., 2013. Nanobiotechnology meets plant cell biology: carbon nanotubes as organelle targeting nanocarriers. RSC Advances, 3(15): 4856-4862. [doi:10.1039/c2ra22766e]

Stampoulis, D., Sinha, S.K., White, J.C., 2009. Assaydependent phytotoxicity of nanoparticles to plants. Environmental Science \& Technology, 43(24):9473-9479. [doi:10.1021/es901695c]

Stark, W.J., 2011. Nanoparticles in biological systems. Angewandte Chemie-International Edition, 50(6):12421258. [doi:10.1002/anie.200906684]

Su, M.Y., Wu, X., Liu, C., et al., 2007. Promotion of energy transfer and oxygen evolution in spinach photosystem II by nano-anatase $\mathrm{TiO}_{2}$. Biological Trace Element Research, 119(2):183-192. [doi:10.1007/s12011-007-0065-1]

Szakal, C., Roberts, S.M., Westerhoff, P., et al., 2014. Measurement of nanomaterials in foods: integrative consideration of challenges and future prospects. ACS Nano, 8(4):3128-3135. [doi:10.1021/nn501108g]

Tepfer, M., Taylor, I.E.P., 1981. The permeability of plant-cell walls as measured by gel-filtration chromatography. Science, 213(4509):761-763. [doi:10.1126/science.213. 4509.761]

Unrine, J.M., Hunyadi, S.E., Tsyusko, O.V., et al., 2010. Evidence for bioavailability of Au nanoparticles from soil and biodistribution within earthworms (Eisenia fetida). Environmental Science \& Technology, 44(21):8308-8313. [doi:10.1021/es101885w]

Unrine, J.M., Shoults-Wilson, W.A., Zhurbich, O., et al., 2012. Trophic transfer of $\mathrm{Au}$ nanoparticles from soil along a simulated terrestrial food chain. Environmental Science \& Technology, 46(17):9753-9760. [doi:10.1021/es3025325]

Wang, H., Kou, X., Pei, Z., et al., 2011. Physiological effects of magnetite $\left(\mathrm{Fe}_{3} \mathrm{O}_{4}\right)$ nanoparticles on perennial ryegrass (Lolium perenne L.) and pumpkin (Cucurbita mixta) plants. Nanotoxicology, 5(1):30-42. [doi:10.3109/ 17435390.2010.489206]

Wang, S., Kurepa, J., Smalle, J.A., 2011. Ultra-small $\mathrm{TiO}_{2}$ nanoparticles disrupt microtubular networks in Arabidopsis thaliana. Plant, Cell and Environment, 34(5):
811-820. [doi:10.1111/j.1365-3040.2011.02284.x]

Wang, Z.Y., Xie, X.Y., Zhao, J., et al., 2012. Xylem- and phloem-based transport of $\mathrm{CuO}$ nanoparticles in maize (Zea mays L.). Environmental Science \& Technology, 46(8):4434-4441. [doi:10.1021/es204212z]

Wild, E., Jones, K.C., 2009. Novel method for the direct visualization of in vivo nanomaterials and chemical interactions in plants. Environmental Science \& Technology, 43(14):5290-5294. [doi:10.1021/es900065h]

Yan, S.H., Zhao, L., Li, H., et al., 2013. Single-walled carbon nanotubes selectively influence maize root tissue development accompanied by the change in the related gene expression. Journal of Hazardous Materials, 246: 110-118. [doi:10.1016/j.jhazmat.2012.12.013]

Yang, F., Liu, C., Gao, F., et al., 2007. The improvement of spinach growth by nano-anatase $\mathrm{TiO}_{2}$ treatment is related to nitrogen photoreduction. Biological Trace Element Research, 119(1):77-88. [doi:10.1007/s12011-007-00464]

Yang, X., Gondikas, A.P., Marinakos, S.M., et al., 2012. Mechanism of silver nanoparticle toxicity is dependent on dissolved silver and surface coating in Caenorhabditis elegans. Environmental Science \& Technology, 46(2): 1119-1127. [doi:10.1021/es202417t]

Zhang, H.F., He, X.A., Zhang, Z.Y., et al., 2011. Nano-CeO $\mathrm{C}_{2}$ exhibits adverse effects at environmental relevant concentrations. Environmental Science \& Technology, 45(8): 3725-3730. [doi:10.1021/es103309n]

Zhang, W.X., 2003. Nanoscale iron particles for environmental remediation: an overview. Journal of Nanoparticle Research, 5(3-4):323-332. [doi:10.1023/A:1025520116 015]

Zhang, Z.Y., He, X., Zhang, H.F., et al., 2011. Uptake and distribution of ceria nanoparticles in cucumber plants. Metallomics, 3(8):816-822. [doi:10.1039/c1mt00049g]

Zhao, L.J., Peng, B., Hernandez-Viezcas, J.A., et al., 2012a. Stress response and tolerance of Zea mays to $\mathrm{CeO}_{2}$ nanoparticles: cross talk among $\mathrm{H}_{2} \mathrm{O}_{2}$, heat shock protein, and lipid peroxidation. ACS Nano, 6(11):9615-9622. [doi:10.1021/nn302975u]

Zhao, L.J., Peralta-Videa, J.R., Ren, M.H., et al., 2012b. Transport of $\mathrm{Zn}$ in a sandy loam soil treated with $\mathrm{ZnO}$ NPs and uptake by corn plants: electron microprobe and confocal microscopy studies. Chemical Engineering Journal, 184:1-8. [doi:10.1016/j.cej.2012.01.041]

Zhao, L.J., Peralta-Videa, J.R., Rico, C.M., et al., 2014. $\mathrm{CeO}_{2}$ and $\mathrm{ZnO}$ nanoparticles change the nutritional qualities of cucumber (Cucumis sativus). Journal of Agricultural and Food Chemistry, 62(13):2752-2759. [doi:10.1021/ jf405476u]

Zheng, L., Hong, F.S., Lu, S.P., et al., 2005. Effect of nano$\mathrm{TiO}_{2}$ on strength of naturally and growth aged seeds of spinach. Biological Trace Element Research, 104(1): 83-91. [doi:10.1385/BTER:104:1:083]

Zhou, D., Jin, S., Li, L., et al., 2011. Quantifying the adsorption and uptake of $\mathrm{CuO}$ nanoparticles by wheat root based 
on chemical extractions. Journal of Environmental Sciences, 23(11):1852-1857. [doi:10.1016/S1001-0742 (10)60646-8]

Zhu, H., Han, J., Xiao, J.Q., et al., 2008. Uptake, translocation, and accumulation of manufactured iron oxide nanoparticles by pumpkin plants. Journal of Environmental
Monitoring, 10(6):713-717. [doi:10.1039/b805998e]

Zhu, X.S., Wang, J.X., Zhang, X.Z., et al., 2010. Trophic transfer of $\mathrm{TiO}_{2}$ nanoparticles from daphnia to zebrafish in a simplified freshwater food chain. Chemosphere, 79(9):928-933. [doi:10.1016/j.chemosphere.2010.03. 022]

\section{中文概要:}

本文题目：纳米材料与农作物之间的相互作用：食品安全与启示

Interactions between engineered nanomaterials and agricultural crops: implications for food safety

研究目的: 通过综述作物对纳米材料的吸收途径和积累, 以及纳米材料对农作物生长和营养的影响, 为 纳米污染在农业中的风险提供理论分析和启示。

创新要点: 归纳了纳米材料被作物吸收的路径和对作物生理、遗传、营养各水平上产生的胁迫。

重要结论: 当前纳米与作物的研究应集中在食品安全相关的问题上, 考虑农业实际情况和环境因素, 分 析纳米材料通过食物链富集和传递的可能性，探讨纳米材料与其他土壤有机污染物可能产生 的复合污染。

关键词组: 纳米材料; 植物吸收; 食物链传递; 食品安全 